\title{
Musculoskeletal networks reveal topological disparity in mammalian neck evolution
}

\author{
Patrick Arnold ${ }^{1,2^{*}}$ (D), Borja Esteve-Altava ${ }^{3}$ and Martin S. Fischer ${ }^{1}$
}

\begin{abstract}
Background: The increase in locomotor and metabolic performance during mammalian evolution was accompanied by the limitation of the number of cervical vertebrae to only seven. In turn, nuchal muscles underwent a reorganization while forelimb muscles expanded into the neck region. As variation in the cervical spine is low, the variation in the arrangement of the neck muscles and their attachment sites (i.e., the variability of the neck's musculoskeletal organization) is thus proposed to be an important source of neck disparity across mammals. Anatomical network analysis provides a novel framework to study the organization of the anatomical arrangement, or connectivity pattern, of the bones and muscles that constitute the mammalian neck in an evolutionary context.

Results: Neck organization in mammals is characterized by a combination of conserved and highly variable network properties. We uncovered a conserved regionalization of the musculoskeletal organization of the neck into upper, mid and lower cervical modules. In contrast, there is a varying degree of complexity or specialization and of the integration of the pectoral elements. The musculoskeletal organization of the monotreme neck is distinctively different from that of therian mammals.
\end{abstract}

Conclusions: Our findings reveal that the limited number of vertebrae in the mammalian neck does not result in a low musculoskeletal disparity when examined in an evolutionary context. However, this disparity evolved late in mammalian history in parallel with the radiation of certain lineages (e.g., cetartiodactyls, xenarthrans). Disparity is further facilitated by the enhanced incorporation of forelimb muscles into the neck and their variability in attachment sites.

Keywords: Anatomical network analysis, Network theory, Forelimb evolution, Mammalian cervical spine, Sloths, Meristic constraints, Modularity

\section{Background}

The increase in locomotor and metabolic performance was one of the most important innovations in the evolution of mammals [1-6]. This innovation, however, was accompanied by an exceptionally low variability in the number of presacral vertebrae compared to other tetrapods (e.g., [7-14]). In fact, the number of cervical vertebrae in mammals is limited to seven, except in extant manatees and sloths [12]. As mammals evolved a new

\footnotetext{
* Correspondence: patrick_arnold@eva.mpg.de

'Department of Human Evolution, Max Planck Institute for Evolutionary

Anthropology, Leipzig, Germany

${ }^{2}$ Institut für Spezielle Zoologie und Evolutionsbiologie mit Phyletischem

Museum, Friedrich-Schiller-Universität Jena, Jena, Germany

Full list of author information is available at the end of the article
}

locomotor mode based on an increase in sagittal axial motions, their back and nuchal muscles underwent an anatomical reorganization $[15,16]$. The epaxonic muscles (particularly the iliocostalis system) were reduced along with the decrease of lateral axial motion $[15,16]$. With the predominance of girdle-limb system as the main propeller in mammals, pectoral muscles also expanded into the dorsal region [15] and were integrated into the head/neck functional unit. Studies on the evolution of the mammalian neck usually have focused on the role of those muscles emigrating from the cervical region during early development [17-20]. In contrast, the muscles that expanded into the neck have been solely investigated for their impact on shoulder and forelimb mechanics (e.g., [21-24]). 
Differences in ecology and size resulted in interspecific differences in the posture and mobility of the head in mammals during standing, locomotion, foraging, oral grooming, and other daily activities (e.g., [25-30]). The morphological basis of these differences, however, is poorly understood. Variation of the cervical column length as a whole has recently been shown to be an important factor in generating morphological disparity of the neck in mammals [31]. As a consequence of the limited variability in the number of vertebrae $[9,12]$ and in vertebral shape $[17,32-35]$, the disparity of the cervical skeleton alone is still low. Hence, we suggest that interspecific variation in the arrangement of the neck muscles plus their attachment sites on the cervical vertebrae, the skull and other bones (i.e., the variability of the musculoskeletal organization) should be an important source of morphological disparity of the neck across mammals. Although there are numerous descriptions of the myology of the neck region for almost every mammalian family, only a few studies compared the neck muscle arrangement interspecifically in an evolutionary context (e.g., [36-39]). Moreover, these studies compared neck muscles only qualitatively, which prevents the quantification of the differentiation of the neck muscles arrangement. As a consequence, it is currently unknown whether the interspecific variation in muscle attachments actually affected the changes of the musculoskeletal organization of the neck across mammals.

Anatomical Network Analysis (AnNA) provides a novel framework to study the organization of the anatomical arrangement of bones and muscles of anatomical structures (i.e., the connectivity pattern) $[40,41]$. Within this framework, bones and muscles are formalized as the nodes of the network, and the physical contacts among them are formalized as the links that connect the network's nodes. Anatomical network models thus offer a mathematical description of the organization of the body [41]. Through such mathematical formalism we can identify and quantify structural patterns, such as anatomical modules, without a priori assumptions about the developmental or functional factors causing them [40] (for a recent review on morphological modularity, see [42]). This allows direct phylogenetic comparisons. In this context, AnNA has been used, for example, to infer evolutionary trends in the skull of tetrapods [43] and the phylogenetic relation between morphological complexity and modularity in the skull of primates [44]. AnNA formalization also allows combining information on skeletal and muscular tissues as it was done to study congenital musculoskeletal malformations [45], secondary injuries [46] in humans, and hindlimb functional integration in frogs [47].

We can also use network parameters as proxies to infer the morphological organization of the body. Table 1 summarizes the network parameters used in this study and their most common morphological interpretation. Further details on the interpretation of network concepts in a morphological context and their historical roots have been given elsewhere (see, e.g., [41, 43, 48-50]). In short, every interpretation derives from the biological role of connections in the network model. Broadly speaking, the connections we have modeled among the bones and muscles of the neck embody functional interactions (e.g., determining the range of neck motion), as well as developmental factors (e.g., those inducing muscles to attach to a specific vertebrae and not to other). Thus, for example, the number of such connections for a given element, or for the entire network (i.e., K), represents the amount of functional and developmental dependences of this element or of the whole network. Functional and developmental dependences are often associated to Rupert Rield's concept of burden, or more generally, to the concept of constrain of body parts [40,51-53]. Morphological interpretation of more elaborated network parameters, such as the density of connections (D), the mean clustering coefficient (C), and the mean shortest path length (L), follow a similar logic. Because connections represent biological interactions among anatomical parts, their relative amount (D) serves as a proxy of the complexity available to the system (e.g., to perform complex functions). In addition to quantifying the amount of connections, the way connections are set (e.g., creating intertwined patterns such as 3-node loops $(C)$ ) and their effects on topology (e.g., increasing the effective proximity of elements to interact together (L)) also have consequences in the overall integration of the anatomy. Thus, the greater the intertwining, the greater the integration; the closer the elements, the greater the integration. Moreover, differences in the amount of connections among the elements of the network (some have many, most have a few) introduces heterogeneity in the organization of the network. Such heterogeneity can be related before to structural disparity (or anisomerism sensu Gregory [43, 54]). Finally, the overall patterns of integration and heterogeneity among the parts of a network often results in the emergence of new properties, for example, modularity [48] (see [55-58] for general reviews on the origin and macroevolution of modularity at a morphological level). The more specific details of the modular organization of a network need a closer observation, but the overall degree of parcellation of the network into large, uniform modules (P) captures how much modular the neck is.

Here we applied AnNA to a phylogenetically broad dataset of mammalian necks, including all bones (cervical vertebrae, cranium, sternum, hyoid and pectoral girdle) and muscles involved in the motion of the head and neck (Fig. 1a-f). First, we modeled the neck of each species as a network in which nodes represented the aforementioned bones and muscles and links represented their physical arrangement or contacts. Then, we 
Table 1 Summary of network parameters used in this study

\begin{tabular}{|c|c|c|}
\hline Network parameter & Mathematical definition & Morphological interpretation \\
\hline Number of nodes $(\mathrm{N})$ & Direct count of the number of nodes in the network & Number of anatomical elements \\
\hline Number of links (K) & Direct count of the number of links in the network & $\begin{array}{l}\text { Number of anatomical relations } \\
\text { (burden or constrain), connectivity }\end{array}$ \\
\hline \multirow[t]{2}{*}{ Density of connections (D) } & Relative amount of links: & \multirow[t]{2}{*}{ Morphological complexity } \\
\hline & $D=\frac{2 K}{N(N-1)}$ & \\
\hline \multirow[t]{3}{*}{ Mean clustering coefficient (C) } & Relative amount of 3-node loops: & \multirow[t]{3}{*}{ Co-dependency (integration) } \\
\hline & $C=\frac{1}{N} \sum \frac{\sum l o o p s_{i}}{k_{i}\left(k_{i}-1\right)}$ & \\
\hline & $\begin{array}{l}\text { where } e_{i} \text { is the existing number of links among the neighbors } \\
\text { of node } i \text { and } k_{i} \text { is the total number of links of a node } i\end{array}$ & \\
\hline \multirow[t]{3}{*}{ Mean shortest path length $(L)$} & Average distance between every pair of nodes: & \multirow[t]{3}{*}{ Effective proximity (integration) } \\
\hline & $L=\frac{1}{N-1} \sum d_{n_{i}, n_{j}}$ & \\
\hline & $\begin{array}{l}\text { where } d \text { is the shortest distance in number of links between } \\
\text { a given pair of nodes } n_{i} \text { and } n_{j}\end{array}$ & \\
\hline \multirow[t]{3}{*}{ Heterogeneity of connections $(\mathrm{H})$} & Disparity in the number of links per node: & \multirow[t]{3}{*}{ Anisomerism } \\
\hline & $H=\sigma_{K} / \mu_{K}$ & \\
\hline & $\begin{array}{l}\text { where } \sigma_{K} \text { and } \mu_{K} \text { are the standard deviation and mean of } K \text {, } \\
\text { respectively }\end{array}$ & \\
\hline \multirow[t]{2}{*}{ Parcellation (P) } & Extent and uniformity of the modular division: & \multirow[t]{2}{*}{ Degree of modularity } \\
\hline & $\begin{array}{l}P=1-\sum\left(N_{m} / N\right)^{2} \\
\text { where } N_{m} \text { is the number of nodes in module } m\end{array}$ & \\
\hline
\end{tabular}

quantified seven network parameters that serve as proxies for the morphological organization of the neck anatomy (Table 1). Finally, we explored the disparity of neck musculoskeletal organization through time to answer, specifically: 1) whether the musculoskeletal organization (as captured by network parameters) of the neck really differs among mammals; 2) whether closely related species share similar network organization; 3) whether there is a consistent pattern of modularity across mammalian necks; 4) how extreme elongation and deviating vertebral numbers alter neck organization; and 5) how disparity in neck anatomical organization changed during mammalian evolutionary history.

\section{Results}

\section{Network parameters and phylogenetic signal}

The values of the network parameters used as proxies for the musculoskeletal organization of the neck for individual taxa are listed in Table 2. The phylogenetic signal is statistically significant for the multivariate dataset of all network parameters (Kmult $=0.89, p<0.001)$ as well as for five of the seven parameters $(N, K, D, H, P$; Table 3, Additional file 1: AF1). This suggests similar variation in neck organization in closely related species (Fig. 2). A Brownian motion model of evolution best explains trait evolution of the network parameters (see Additional file 1: AF1). Relative variability in connectivity $K$, complexity $D$, and integration by co-dependency $C$ is high among the species examined (significant higher coefficients of variation; $\mathrm{Msrl}=139.58, p<0.001$ ) (Table 3, Additional file 1: AF1). In contrast, relative variability of integration by effective proximity $L$, anisomerism $H$, and the degree of modularity $P$ are low across all mammals (Table 3, Additional file: AF1). There is no significant relationship between the network parameters and either body mass $(\mathrm{F}=0.170, p=0.68)$, absolute neck length $(\mathrm{F}=0.005, p=0.94)$, relative neck length $(\mathrm{F}=0.661$, $p=0.42$ ), or predatory behavior (i.e., predatory vs. nonpredatory; $\mathrm{F}=0.191, \mathrm{p}=0.68$ ).

The number of anatomical elements $N$ is low in monotremes compared to the general pattern of therians (Fig. 2a). However, most xenarthrans, the chiropterans, and the Pygmy sperm whale (Kogia breviceps) also have a decreased number of elements in their neck network. The number of anatomical connections $\mathrm{K}$ is uniformly high in marsupials in contrast to most other mammals (Fig. 2b). $K$ is decreased in monotremes, xenarthrans, chiropterans, the Pygmy sperm whale and the Bactrian camel (Camelus bactrianus). Morphological complexity $D$ is high in monotremes, intermediate in marsupials and xenarthrans and tends to decrease in most of the other placental lineages (Fig. 2c). For H, the largest contrast can be found between monotremes (very low $\mathrm{H}$ ) and therians in general, whereas the pattern within therians is not uniform (Fig. 2d). The degree of modularity $P$ is relatively invariable and only slight decreases can be found in diprotodonts, Pen-tailed treeshrew (Ptilocercus lowii), chiropterans and eulipotyphlans (Fig. 2e). The 

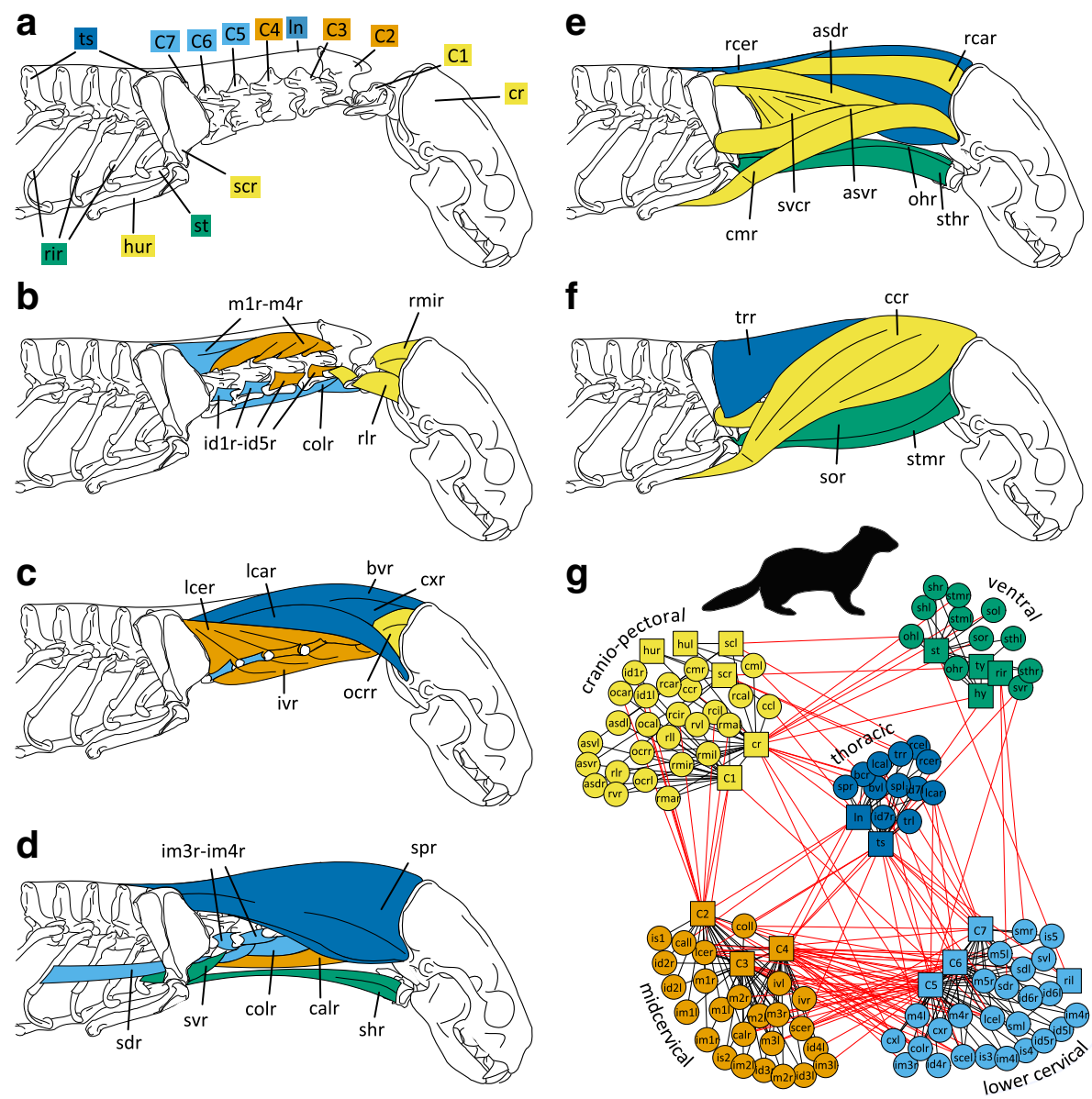

Fig. 1 Musculoskeletal anatomy of the mammalian neck and its translation into the anatomical network. a Skeletal and (b-f) muscular elements of the neck included in the analysis (from deep to superficial) exemplified for the lesser grison (Galictis cuja). $\mathbf{g}$ Anatomical network representing the same topological information. Colors code for the identified connectivity modules. Red links between-modules. Black links within modules. a-f adopted and modified after [138, 139]

phylomorphospace (Fig. 3; Additional file 1: AF1) highlights the differences in neck musculoskeletal organization between monotreme and therian mammals $(\mathrm{F}=1.695, p<$ 0.001). Marsupials cluster closely together. They slightly overlap with the distribution of placental mammal, which occupy a huge part of the morphospace. The Pygmy sperm whale is far from the other placental mammals.

\section{Community structure and phenotypic modules in neck networks}

The number and constitution of the connectivity modules in the neck varies among the mammalian species examined (a summary is given in Table 4; for detailed information see Additional file 1: AF1). In many cases however, module number varies based on a left-right split of modules that are united in other species (e.g., the pectoral elements are separated in left and right modules). Overall, five principal connectivity modules were detected: 1) cranio-pectoral, 2) ventral, 3) mid-cervical, 4) lower cervical, and 5) thoracic.
This pattern is exemplified here for the lesser grison (Galictis cuja) (Fig. 1g). The cranio-pectoral module (present in 32 out of 48 taxa) groups the cranium, the $\mathrm{C} 1$, and the bones of the pectoral girdle (scapulae, claviculae, and, if included, humeri), as well as the suboccipital, cleidocephalic (or cephalohumeralis), atlantoscapularis, capital longus, and capital rhomboid muscles. The ventral module groups the sternum, hyoid, thyroid, mandible (when included), and the sternocephalic and infrahyoid muscles. In 32 out of 48 cases, ribs and the related scalenii muscles are also included in this module. The ventral module is combined with (parts of) the pectoral bones and muscles in 15 species, none of which are aclaviculate (Fig. 4b). The mid-cervical module groups $\mathrm{C} 2$ to $\mathrm{C} 4$ as well as the longus cervicis, spinalis, and their related interspinal, intertransversarii, and multifidii muscles. The lower cervical module groups $\mathrm{C} 5$ to $\mathrm{C} 7$ with the cervical longissimus, spinalis, and their related interspinal, intertransversarii, and multifidi muscles. These midcervical and lower cervical modules are present in all 
Table 2 Network parameters of the musculoskeletal organization of the neck of 48 mammalian species

\begin{tabular}{|c|c|c|c|c|c|c|c|c|}
\hline Order & Species & $\mathrm{N}$ & K & $\mathrm{D}$ & C & $\mathrm{L}$ & $\mathrm{H}$ & $P$ \\
\hline \multirow[t]{2}{*}{ Afrosoricida } & Chrysospalax trevelyani & 112 & 328 & 0.053 & 0.456 & 2.81 & 1.448 & 0.820 \\
\hline & Micropotamogale ruwenzorii & 108 & 329 & 0.057 & 0.482 & 2.771 & 1.449 & 0.784 \\
\hline \multirow[t]{5}{*}{ Carnivora } & Canis lupus & 123 & 368 & 0.049 & 0.351 & 2.714 & 1.529 & 0.784 \\
\hline & Civettictis civetta & 113 & 357 & 0.056 & 0.468 & 2.706 & 1.504 & 0.767 \\
\hline & Felis silvestris & 103 & 320 & 0.061 & 0.452 & 2.65 & 1.401 & 0.784 \\
\hline & Galictis cuja & 118 & 322 & 0.047 & 0.448 & 2.928 & 1.416 & 0.780 \\
\hline & Zalophus californianus & 118 & 338 & 0.049 & 0.479 & 2.795 & 1.43 & 0.801 \\
\hline \multirow[t]{5}{*}{ Cetartiodactyla } & Babyrousa babyrussa & 106 & 344 & 0.062 & 0.398 & 2.734 & 1.409 & 0.784 \\
\hline & Bos taurus & 108 & 329 & 0.057 & 0.41 & 2.777 & 1.395 & 0.789 \\
\hline & Camelus bactrianus & 96 & 232 & 0.051 & 0.295 & 2.903 & 1.268 & 0.771 \\
\hline & Giraffa camelopardalis & 106 & 309 & 0.056 & 0.435 & 2.731 & 1.421 & 0.793 \\
\hline & Kogia breviceps & 96 & 219 & 0.048 & 0.488 & 3.099 & 1.316 & 0.825 \\
\hline \multirow[t]{2}{*}{ Chiroptera } & Pteropus vampyrus & 92 & 260 & 0.062 & 0.452 & 2.778 & 1.329 & 0.732 \\
\hline & Vespertilio murinus & 96 & 264 & 0.058 & 0.476 & 2.821 & 1.358 & 0.729 \\
\hline Cingulata & Dasypus novemcinctus & 95 & 279 & 0.062 & 0.524 & 2.769 & 1.331 & 0.844 \\
\hline Dasyuromorpha & Sarcophilus harrisii & 118 & 390 & 0.056 & 0.449 & 2.714 & 1.502 & 0.779 \\
\hline Didelphimorphia & Didelphis virginiana & 108 & 374 & 0.065 & 0.385 & 2.668 & 1.413 & 0.795 \\
\hline \multirow[t]{3}{*}{ Diprotodontia } & Macropus rufus & 112 & 355 & 0.057 & 0.446 & 2.726 & 1.425 & 0.725 \\
\hline & Phascolarctos cinereus & 119 & 397 & 0.057 & 0.429 & 2.699 & 1.538 & 0.710 \\
\hline & Trichosurus vulpecula & 109 & 348 & 0.059 & 0.402 & 2.743 & 1.432 & 0.725 \\
\hline \multirow[t]{3}{*}{ Eulipotyphla } & Erinaceus europaeus & 104 & 330 & 0.062 & 0.441 & 2.747 & 1.419 & 0.734 \\
\hline & Scalopus aquaticus & 108 & 322 & 0.056 & 0.425 & 2.788 & 1.439 & 0.728 \\
\hline & Suncus murinus & 104 & 304 & 0.057 & 0.411 & 2.835 & 1.418 & 0.753 \\
\hline Hyracoidea & Procavia capensis & 115 & 340 & 0.052 & 0.451 & 2.84 & 1.507 & 0.815 \\
\hline Lagomorpha & Oryctolagus cuniculus & 122 & 343 & 0.046 & 0.422 & 2.831 & 1.556 & 0.786 \\
\hline \multirow[t]{2}{*}{ Monotremata } & Ornithorhynchus anatinus & 84 & 282 & 0.081 & 0.382 & 2.575 & 1.179 & 0.765 \\
\hline & Tachyglossus aculeatus & 85 & 260 & 0.073 & 0.389 & 2.709 & 1.183 & 0.791 \\
\hline Notoryctemorphia & Notoryctes typhlops & 112 & 363 & 0.058 & 0.455 & 2.736 & 1.485 & 0.806 \\
\hline Paucituberculata & Caenolestes fuliginosus & 122 & 383 & 0.052 & 0.435 & 2.767 & 1.544 & 0.770 \\
\hline Peramelemorphia & Macrotis lagotis & 120 & 396 & 0.055 & 0.434 & 2.72 & 1.541 & 0.790 \\
\hline \multirow[t]{2}{*}{ Perissodactyla } & Equus caballus & 124 & 327 & 0.043 & 0.454 & 2.874 & 1.555 & 0.774 \\
\hline & Tapirus indicus & 114 & 321 & 0.05 & 0.463 & 2.862 & 1.463 & 0.815 \\
\hline Pholidota & Manis pentadactyla & 101 & 292 & 0.058 & 0.456 & 2.873 & 1.375 & 0.791 \\
\hline \multirow[t]{3}{*}{ Pilosa } & Bradypus tridactylus & 110 & 318 & 0.053 & 0.548 & 2.909 & 1.293 & 0.782 \\
\hline & Choloepus didactylus & 90 & 255 & 0.064 & 0.489 & 2.708 & 1.339 & 0.762 \\
\hline & Cyclopes didactylus & 96 & 260 & 0.057 & 0.456 & 2.917 & 1.319 & 0.820 \\
\hline \multirow[t]{3}{*}{ Primates } & Homo sapiens & 113 & 334 & 0.053 & 0.512 & 2.712 & 1.442 & 0.793 \\
\hline & Loris tardigradus & 114 & 344 & 0.053 & 0.352 & 2.731 & 1.47 & 0.808 \\
\hline & Macaca mulatta & 122 & 369 & 0.05 & 0.344 & 2.719 & 1.504 & 0.812 \\
\hline Proboscidea & Elephas maximus & 110 & 273 & 0.046 & 0.439 & 2.829 & 1.424 & 0.797 \\
\hline \multirow[t]{4}{*}{ Rodentia } & Chinchilla lanigera & 108 & 320 & 0.055 & 0.404 & 2.761 & 1.423 & 0.831 \\
\hline & Heteromys desmarestianus & 96 & 294 & 0.064 & 0.356 & 2.719 & 1.256 & 0.803 \\
\hline & Neotoma fuscipes & 120 & 333 & 0.047 & 0.409 & 2.825 & 1.521 & 0.814 \\
\hline & Pedetes capensis & 112 & 323 & 0.052 & 0.434 & 2.775 & 1.474 & 0.802 \\
\hline
\end{tabular}


Table 2 Network parameters of the musculoskeletal organization of the neck of 48 mammalian species (Continued)

\begin{tabular}{lllllllll}
\hline Order & Species & $\mathrm{N}$ & $\mathrm{K}$ & $\mathrm{D}$ & $\mathrm{C}$ & $\mathrm{L}$ & $\mathrm{H}$ & $\mathrm{P}$ \\
\hline \multirow{3}{*}{ Scandentia } & Sciurus vulgaris & 130 & 364 & 0.043 & 0.421 & 2.807 & 1.575 & 0.780 \\
Sirenia & Ptilocercus lowii & 114 & 336 & 0.052 & 0.483 & 2.785 & 1.49 & 0.719 \\
Tubulidentata & Dugong dugon & 106 & 310 & 0.056 & 0.505 & 2.782 & 1.413 & 0.795 \\
\hline
\end{tabular}

$N$ Number of elements, $K$ Number of connections, $D$ Density of connections, $C$ Mean clustering coefficient, $L$ Mean shortest path length, $H$ Heterogeneity of connections, $P$ Parcellation index

networks (Fig. 4a-d). The border between them is, however, shifted in some species (e.g., C4/C5 to C3/C4). If the attachments of scalenii muscles are limited to few specific cervical vertebrae, these muscle and the ribs are also included in the mid or lower cervical module. The thoracic module groups the thoracic spine, nuchal ligament, semispinalis (complexus + biventer cervicis), capital longissimus, cervical rhomboid and trapezius muscle.

In several species, the pectoral bones (plus the related muscles) are not grouped together with the cranium and C1 but separated; otherwise they are included in the ventral or thoracic module, respectively. For instance, in the long-necked camel the pectoral bones and muscles constitute a distinct module together with the nuchal ligament (Fig. 4c). In the giraffe (Giraffa camelopardalis), attachment sites of the pectoral muscles are shifted proximally to the midcervical module. In contrast, the pectoral bones and muscles are combined with the ventral elements into a ventro-pectoral unit in the particolored bat (Vespertilio murinus) (Fig. 4b). The sloths differ in the organization of their neck due to their aberrant number of cervical vertebrae. In the two-toed sloth (Choloepus didactylus; six cervical vertebrae), the pectoral elements form a separate module. The C5, C6, thoracic spine, and related muscles are grouped within one module. In the three-toed sloth (Bradypus tridactylus; nine cervical vertebrae; Fig. 4d), there is an upper (C2-C5) and lower (C6-C7) midcervical module. The evolutionary 'new' vertebrae $\mathrm{C} 8$ and $\mathrm{C}$, however, are grouped with the thoracic spine, scapulae, and related muscles. The claviculae are included in the ventral module. The ribs are grouped with the cranium and atlas in the Pygmy sperm whale.

\section{Disparity in neck organization through time}

The mean subclade disparity values for the observed and simulated data were plotted against node age (Fig. 2f). Subclade disparity through time is low, which is particularly obvious in the first two-thirds of mammalian evolution (i.e., during the Mesozoic). However, it is not significantly different from the expectation under a Brownian motion model of neck organizational evolution (morphological disparity index $=0.016, p=0.65$ ). Nevertheless, major shifts in disparity rate occurred in the middle to late Paleocene and in the middle to late Eocene. These shifts resulted in disparity peaks exceeding the $95 \%$ confidence interval of the simulated data. The disparity in neck musculoskeletal organization decreased after the Eocene-Oligocene border. A larger sample size would be required to infer significant results for the post-Eocene ages (i.e., more divergence events are needed).

\section{Discussion}

\section{Variation in neck organization across phylogeny}

The more conserved network parameters $(L, H, P)$ represent measurements of the neck's integration by effective proximity, anisomerism, and degree of modularity

Table 3 Variability and phylogenetic signal in neck network parameters

\begin{tabular}{|c|c|c|c|c|c|c|c|}
\hline & $\mathrm{N}$ & $\mathrm{K}$ & $\mathrm{D}$ & C & $\mathrm{L}$ & $\mathrm{H}$ & $P$ \\
\hline Minimum & 84 & 219 & 0.043 & 0.295 & 2.575 & 1.179 & 0.71 \\
\hline 1st Quartil & 102.5 & 293.5 & 0.052 & 0.41 & 2.72 & 1.371 & 0.769 \\
\hline Mean & 108.6 & 321.5 & 0.056 & 0.437 & 2.782 & 1.421 & 0.782 \\
\hline 3rd Quartil & 115.8 & 345 & 0.058 & 0.464 & 2.83 & 1.493 & 0.802 \\
\hline Maximum & 130 & 397 & 0.081 & 0.548 & 3.099 & 1.575 & 0.844 \\
\hline Coefficient of Variation & 0.097 & 0.132 & 0.128 & 0.114 & 0.031 & 0.066 & 0.04 \\
\hline 95\% Confidence Intervalls & $0.077 / 0.115$ & $0.104 / 0.155$ & $0.092 / 0.16$ & $0.085 / 0.138$ & $0.022 / 0.04$ & $0.051 / 0.079$ & $0.032 / 0.047$ \\
\hline Abouheif's Cmean & $0.372^{* * *}$ & $0.421^{* * *}$ & $0.366^{* * *}$ & 0.133 & 0.172 & $0.359^{* * *}$ & $0.354^{* * *}$ \\
\hline Blomberg's K & $0.995^{* * *}$ & $0.879^{* * *}$ & $1.479 * * *$ & 0.559 & 0.762 & $1.108^{* * *}$ & $0.719^{* *}$ \\
\hline
\end{tabular}

$N$ Number of elements, $K$ Number of connections, $D$ Density of connections, $C$ Mean clustering coefficient, $L$ Mean shortest path length, $H$ Heterogeneity of connections, $P$ Parcellation index. Significance levels of the tests for phylogenetic signal: $p<0.01^{* *} ; p<0.001^{* * *}$ 

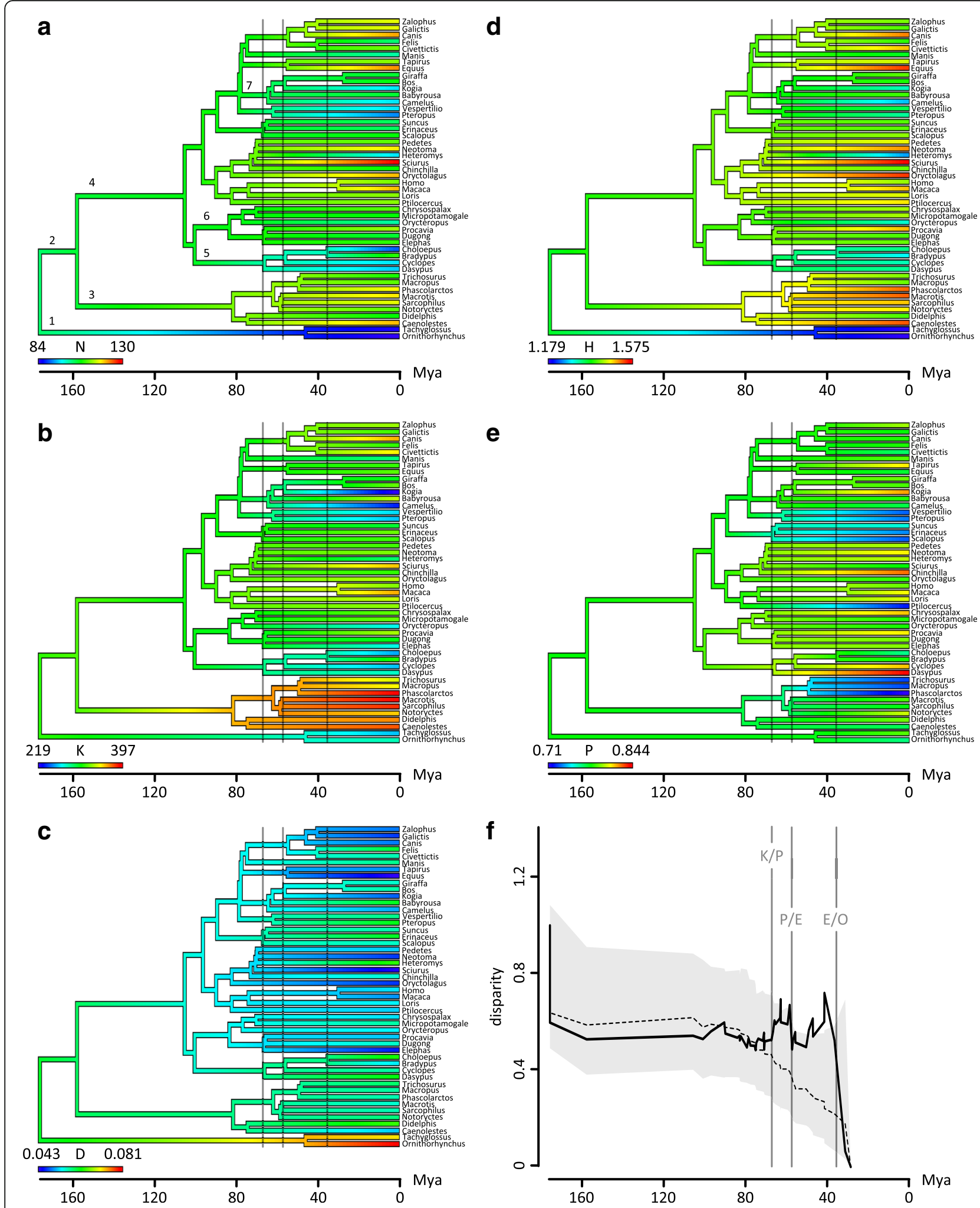

Fig. 2 (See legend on next page.) 
(See figure on previous page.)

Fig. 2 Phylogenetic signal and disparity through time (DTT) for neck network parameters across mammals. a Number of elements $N$; (b) Number of connections $K_{;}$(c) Density of connections $D_{i}$ (d) Heterogeneity of connections $H_{;}$(e) Parcellation index $P_{;}$( $\mathbf{f}$ ) mean subclade disparity through time plot. Gray vertical lines indicate Cretaceous-Tertiary $(\mathrm{K} / \mathrm{T})$ Paleocen-Eocene $(\mathrm{P} / \mathrm{E})$, and Eocene-Oligocene (E/O) boundary. Numbers indicate selected taxa: 1 Monotremata: 2 Theria; 3 Marsupialia; 4 Placentalia; 5 Xenarthra; 6 Afrotheria; 7 Cetartiodactyla. In (f). the solid line indicates actual median subclade DTT of the sample. The dashed line indicates the median subclade DTT based on 10,000 simulations of character evolution under Brownian motion. The shaded area indicates the 95\% DTT range for the simulated data

$[41,43]$. These measurements capture how distant parts of the neck (e.g., head and trunk, lower and upper cervical column) are integrated, that anatomical connections are not evenly distributed across bone (e.g. vertebrae) and the way the neck is modularized. Thus, our results indicate a basic constructional set-up of the neck across mammals determined by morphological regionalization (see further below). These conserved features likely arise due to shared developmental $[8,9,17,19,59-61]$ and/or biomechanical/ constructional constraints $[31,62,63]$. However, the musculoskeletal organization of the neck is not uniform for other morphological features captured by network proxies. Specifically, mammalian necks considerably vary in terms of their morphological burden, complexity, and integration by co-dependency (quantified by $K, D$, and $C$, respectively). These features describe the grade of specialization in the neck due to reduction of elements or

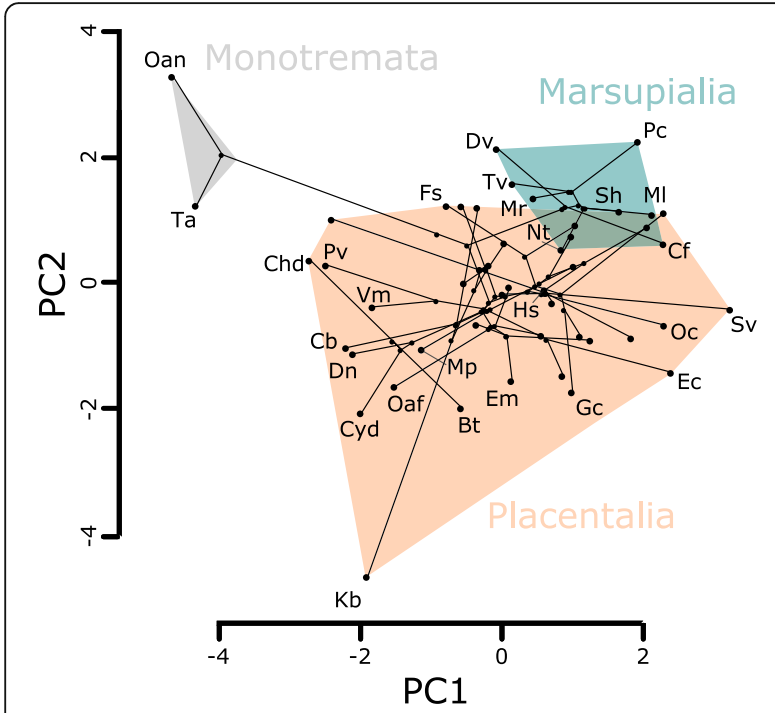

Fig. 3 Phylomorphospace of the network parameters. Monotreme, marsupial and selected placental species are labeled. PC1 and PC2 represent $44 \%$ and $27 \%$ of the total variation, respectively. Species abbreviations: Bt Bradypus tridactylus; $\mathrm{Cb}$ Camelus bactrianus; if caenolestes fuliginosus; Chd Choloepus didactylus; Cyd Cyclopes didactylus; Dn Dasypus novemcinctus; Dv Didelphis virginiana; Ec Equus caballus; Em Elephas maximus; Fs Felis silvestris; Gc Galictis cuja; Hs Homo sapiens; Kb Kogia breviceps; Ml Macrotis lagotis; Mp Manis pentadactyla; Mr. Macropus rufus; Nt Notoryctes typhlops; Oaf Orycteropus afer; Oan Ornithorhynchus anatinus; Oc Oryctolagus cuniculus; PC Phascolarctos cinereus; Pv Pteropus vampyrus; Sh Sarcophilus harrisii; Sv Sciurus vulgaris; Ta Tachyglossus aculeatus; Tv Trichosurus vulpecula; Vm Vespertilio murinus enhancement of passive structures (e.g., the nuchal ligament) and the way the neck is structurally constrained by the setup of its muscular connections (i.e., its evolvability) $[43,49]$. The variation arises from the major trends of epaxonic muscle modification during mammalian evolution, leading to differences in nuchal muscle organization among monotremes, marsupials and therians. Our findings confirm the plesiomorphic pattern of epaxonic neck muscle arrangement in monotremes [64-67]. It results in a musculoskeletal organization that is distinctively different from that of therian mammals (Fig. 3). Their low differentiation within the three longitudinal systems (longissimus, iliocostalis, transversospinalis; in particular the deep intervertebral muscles; low number of muscles) and muscle attachments that are evenly distributed among the vertebrae (high complexity but low irregularity) suggest low specialization to specific neck motion patterns. In marsupials, epaxonic muscles are more differentiated in deep and superficial layers. Moreover, most of the superficial muscles are attached to every cervical vertebra [66, 68-72]. This high connectivity results in structural constraints in the neck (i.e., morphological burdens) and low musculoskeletal disparity among marsupials in comparison to placentals (Fig. 3). Attachments of epaxonic neck muscles are very variable among placental mammals [70] and thus network parameters are as well. However, two major trends in neck evolution have been shown: First, there is a reduction of attachment sites of the neck muscles to only a few vertebrae/ the skull; and second, there is an increased bracing of the head-trunk distance by ligamentous structures to accommodate for increasing head weight and neck length [15, 73-78]. This results in placental mammals generally having necks that are less complex compared to monotreme and marsupial mammals. For instance, few but specialized muscles have the small attachment sites and are able to induce a similar motion or the superficial epaxonic muscles attach only secondarily to the head via the nuchal ligament. In addition, neck variation in placental mammals is also highly influenced by variation in the organization of pectoral bones and muscles (see below).

The phylogenetic signal of most of the network parameters reveals that phylogenetic relationship accounts for much of the variation in neck organization. At the same time, network parameters also discriminate between monotreme, marsupial, and placental mammals. Within placental mammals, however, variation of network parameters 
Table 4 Summary of network modules

\begin{tabular}{|c|c|c|c|c|c|c|}
\hline Order & Species & M1 & M2 & M3 & M4 & M5 \\
\hline \multirow[t]{2}{*}{ Afrosoricida } & Chrysospalax trevelyani & $\begin{array}{l}\text { cranio-atlantal } \\
\text { pectoral }\end{array}$ & midcervcial & $\begin{array}{l}\text { lower cervical - } \\
\text { thoracic }\end{array}$ & ventral & \\
\hline & Micropotamogale ruwenzorii & cranio-atlantal & midcervcial $^{a}$ & $\begin{array}{l}\text { lower cervical - } \\
\text { thoracic }\end{array}$ & ventral & pectoral \\
\hline \multirow[t]{5}{*}{ Carnivora } & Canis lupus & $\begin{array}{l}\text { cranio-atlantal } \\
\text { pectoral }\end{array}$ & midcervical & lower cervical & ventral & thoracic \\
\hline & Civettictis civetta & $\begin{array}{l}\text { cranio-atlantal } \\
\text { pectoral }\end{array}$ & midcervcial & $\begin{array}{l}\text { lower cervical - } \\
\text { thoracic }\end{array}$ & ventral & \\
\hline & Felis silvestris & $\begin{array}{l}\text { cranio-atlantal } \\
\text { pectoral }\end{array}$ & midcervcial & lower cervical & ventral & thoracic \\
\hline & Galictis cuja & $\begin{array}{l}\text { cranio-atlantal } \\
\text { pectoral }\end{array}$ & midcervcial & lower cervical & ventral & thoracic \\
\hline & Zalophus californianus & cranio-atlantal & midcervcial & $\begin{array}{l}\text { lower cervical - } \\
\text { thoracic }\end{array}$ & ventral & pectoral \\
\hline \multirow[t]{5}{*}{ Cetartiodactyla } & Babyrousa babyrussa & $\begin{array}{l}\text { cranio-atlantal } \\
\text { humeral }\end{array}$ & midcervical & $\begin{array}{l}\text { lower cervical - } \\
\text { thoracic }\end{array}$ & ventral & scapular \\
\hline & Bos taurus & $\begin{array}{l}\text { cranio-atlantal } \\
\text { humeral }\end{array}$ & midcervcial & $\begin{array}{l}\text { lower cervical - } \\
\text { thoracic }\end{array}$ & ventral & scapular \\
\hline & Camelus bactrianus & cranio-atlantal & midcervical & $\begin{array}{l}\text { lower cervical - } \\
\text { thoracic }\end{array}$ & ventral & pectoral \\
\hline & Giraffa camelopardalis & cranio-atlantal & $\begin{array}{l}\text { midcervcial- } \\
\text { pectoral }\end{array}$ & lower cervical & ventral & thoracic \\
\hline & Kogia breviceps & $\begin{array}{l}\text { cranio-atlantal } \\
\text { costal }\end{array}$ & midcervcial & $\begin{array}{l}\text { lower cervical - } \\
\text { thoracic }\end{array}$ & ventral & pectoral \\
\hline \multirow[t]{2}{*}{ Chiroptera } & Pteropus vampyrus & cranio-atlantal & midcervcial & $\begin{array}{l}\text { lower cervical - } \\
\text { thoracic }\end{array}$ & ventro-pectoral & \\
\hline & Vespertilio murinus & cranio-atlantal & midcervcial & lower cervical - thoracic & ventro-pectoral & \\
\hline Cingulata & Dasypus novemcinctus & $\begin{array}{l}\text { cranio-atlantal } \\
\text { axial }\end{array}$ & midcervcial & lower cervical & ventral & thoracic \\
\hline Dasyuromorpha & Sarcophilus harrisii & cranio-atlantal & midcervcial & $\begin{array}{l}\text { lower cervical - } \\
\text { thoracic }\end{array}$ & ventral & pectoral \\
\hline Didelphimorphia & Didelphis virginiana & $\begin{array}{l}\text { cranio-atlantal } \\
\text { pectoral }\end{array}$ & midcervcial & $\begin{array}{l}\text { lower cervical - } \\
\text { thoracic }\end{array}$ & ventral & \\
\hline \multirow[t]{3}{*}{ Diprotodontia } & Macropus rufus & $\begin{array}{l}\text { cranio-atlantal } \\
\text { pectoral }\end{array}$ & midcervcial & $\begin{array}{l}\text { lower cervical - } \\
\text { thoracic }\end{array}$ & ventral $^{d}$ & \\
\hline & Phascolarctos cinereus & $\begin{array}{l}\text { cranio-atlantal } \\
\text { pectoral }\end{array}$ & midcervcial & $\begin{array}{l}\text { lower cervical - } \\
\text { thoracic }\end{array}$ & ventral & \\
\hline & Trichosurus vulpecula & $\begin{array}{l}\text { cranio-atlantal } \\
\text { pectoral }\end{array}$ & midcervcial & $\begin{array}{l}\text { lower cervical - } \\
\text { thoracic }\end{array}$ & ventral & \\
\hline \multirow[t]{3}{*}{ Eulipotyphla } & Erinaceus europaeus & $\begin{array}{l}\text { cranio-atlantal } \\
\text { pectoral }\end{array}$ & midcervcial & $\begin{array}{l}\text { lower cervical - } \\
\text { thoracic }\end{array}$ & ventral & \\
\hline & Scalopus aquaticus & $\begin{array}{l}\text { cranio-atlantal } \\
\text { pectoral }\end{array}$ & midcervcial & $\begin{array}{l}\text { lower cervical - } \\
\text { thoracic }\end{array}$ & ventral & \\
\hline & Suncus murinus & atlantal & midcervcial & $\begin{array}{l}\text { lower cervical - } \\
\text { thoracic }\end{array}$ & $\begin{array}{l}\text { cranio-ventro- } \\
\text { pectoral }\end{array}$ & costal \\
\hline Hyracoidea & Procavia capensis & $\begin{array}{l}\text { cranio-atlantal } \\
\text { pectoral }\end{array}$ & midcervcial & lower cervical & ventral & thoracic \\
\hline Lagomorpha & Oryctolagus cuniculus & $\begin{array}{l}\text { cranio-atlantal } \\
\text { pectoral }\end{array}$ & midcervical $^{b}$ & $\begin{array}{l}\text { lower cervical - } \\
\text { thoracic }\end{array}$ & ventral & \\
\hline \multirow[t]{2}{*}{ Monotremata } & Ornithorhynchus anatinus & cranio-atlantal & midcervcial & $\begin{array}{l}\text { lower cervical - } \\
\text { thoracic }\end{array}$ & $\begin{array}{l}\text { ventro- } \\
\text { pectoral }\end{array}$ & \\
\hline & Tachyglossus aculeatus & & midcervcial & & ventral & pectoral \\
\hline
\end{tabular}


Table 4 Summary of network modules (Continued)

\begin{tabular}{|c|c|c|c|c|c|c|}
\hline Order & Species & M1 & $\mathrm{M} 2$ & M3 & M4 & M5 \\
\hline & & $\begin{array}{l}\text { cranio-atlantal } \\
\text { axial }\end{array}$ & & $\begin{array}{l}\text { lower cervical - } \\
\text { thoracic }\end{array}$ & & \\
\hline Notoryctemorphia & Notoryctes typhlops & cranio-atlantal & midcervcial & lower cervical & $\begin{array}{l}\text { ventro- } \\
\text { pectoral }\end{array}$ & thoracic \\
\hline Paucituberculata & Caenolestes fuliginosus & $\begin{array}{l}\text { cranio-atlantal } \\
\text { pectoral }\end{array}$ & midcervical $^{\complement}$ & $\begin{array}{l}\text { lower cervical - } \\
\text { thoracic }\end{array}$ & ventral & \\
\hline Peramelemorphia & Macrotis lagotis & $\begin{array}{l}\text { cranio-atlantal } \\
\text { pectoral }\end{array}$ & midcervcial $^{a}$ & $\begin{array}{l}\text { lower cervical - } \\
\text { thoracic }\end{array}$ & ventral & \\
\hline \multirow[t]{2}{*}{ Perissodactyla } & Equus caballus & $\begin{array}{l}\text { cranio-atlantal } \\
\text { pectoral }\end{array}$ & midcervcial & lower cervical & ventral & thoracic \\
\hline & Tapirus indicus & $\begin{array}{l}\text { cranio-atlantal } \\
\text { pectoral }\end{array}$ & midcervcial & lower cervical & ventral & thoracic \\
\hline Pholidota & Manis pentadactyla & $\begin{array}{l}\text { cranio-atlantal } \\
\text { pectoral }\end{array}$ & midcervical $^{\mathrm{b}}$ & $\begin{array}{l}\text { lower cervical - } \\
\text { thoracic }\end{array}$ & ventral & \\
\hline \multirow[t]{3}{*}{ Pilosa } & Bradypus tridactylus & cranio-atlantal & $\begin{array}{l}\text { upper } \\
\text { midcervical }\end{array}$ & $\begin{array}{l}\text { lower } \\
\text { midcervical }\end{array}$ & $\begin{array}{l}\text { ventro- } \\
\text { clavicular }\end{array}$ & $\begin{array}{l}\text { lower cervical - } \\
\text { thoracic scapular }\end{array}$ \\
\hline & Choloepus didactylus & cranio-atlantal & midcervcial & $\begin{array}{l}\text { lower cervical - } \\
\text { thoracic }\end{array}$ & ventral & pectoral \\
\hline & Cyclopes didactylus & cranio-atlantal & $\begin{array}{l}\text { midcervcial - } \\
\text { thoracic }\end{array}$ & $\begin{array}{l}\text { lower cervical } \\
\text { C5\&rest }\end{array}$ & ventral & pectoral \\
\hline \multirow[t]{3}{*}{ Primates } & Homo sapiens & cranio-atlantal & midcervical $^{\mathrm{b}}$ & $\begin{array}{l}\text { lower cervical - } \\
\text { thoracic }\end{array}$ & ventral & pectoral \\
\hline & Loris tardigradus & $\begin{array}{l}\text { cranio-atlantal } \\
\text { pectoral }\end{array}$ & midcervcial $^{a}$ & $\begin{array}{l}\text { lower cervical - } \\
\text { thoracic }\end{array}$ & ventral & thoracic \\
\hline & Macaca mulatta & $\begin{array}{l}\text { cranio-atlantal } \\
\text { pectoral }\end{array}$ & midcervical $^{c}$ & $\begin{array}{l}\text { lower cervical - } \\
\text { thoracic }\end{array}$ & ventral & costal \\
\hline Proboscidea & Elephas maximus & $\begin{array}{l}\text { cranio-atlantal } \\
\text { pectoral }\end{array}$ & midcervical $^{\complement}$ & $\begin{array}{l}\text { lower cervical - } \\
\text { thoracic }\end{array}$ & ventral & \\
\hline \multirow[t]{5}{*}{ Rodentia } & Chinchilla lanigera & $\begin{array}{l}\text { cranio-atlantal } \\
\text { scapular }\end{array}$ & midcervical & lower cervical & $\begin{array}{l}\text { ventro- } \\
\text { clavicular }\end{array}$ & thoracic \\
\hline & Heteromys desmarestianus & cranio-atlantal & midcervcial & $\begin{array}{l}\text { lower cervical - } \\
\text { thoracic }\end{array}$ & ventral & pectoral \\
\hline & Neotoma fuscipes & $\begin{array}{l}\text { cranio-atlantal } \\
\text { pectoral }\end{array}$ & midcervical & $\begin{array}{l}\text { lower cervical - } \\
\text { thoracic }\end{array}$ & ventral & \\
\hline & Pedetes capensis & $\begin{array}{l}\text { cranio-atlantal } \\
\text { pectoral }\end{array}$ & midcervcial $^{a}$ & $\begin{array}{l}\text { lower cervical - } \\
\text { thoracic }\end{array}$ & ventral & \\
\hline & Sciurus vulgaris & $\begin{array}{l}\text { cranio-atlantal } \\
\text { scapular }\end{array}$ & midcervcial & $\begin{array}{l}\text { lower cervical - } \\
\text { thoracic }\end{array}$ & $\begin{array}{l}\text { ventro- } \\
\text { clavicular }\end{array}$ & \\
\hline Scandentia & Ptilocercus lowii & $\begin{array}{l}\text { cranio-atlantal } \\
\text { pectoral }\end{array}$ & midcervcial & $\begin{array}{l}\text { lower cervical - } \\
\text { thoracic }\end{array}$ & ventral & \\
\hline Sirenia & Dugong dugon & $\begin{array}{l}\text { cranio-atlantal } \\
\text { pectoral }\end{array}$ & midcervcial & lower cervical & ventral & thoracic \\
\hline Tubulidentata & Orycteropus afer & $\begin{array}{l}\text { cranio-atlantal } \\
\text { pectoral }\end{array}$ & midcervical $^{\mathrm{b}}$ & $\begin{array}{l}\text { lower cervical - } \\
\text { thoracic }\end{array}$ & ventral & \\
\hline
\end{tabular}

Contribution of the pectoral elements to different modules marked in bold. Left-right division of pectoral and costal elements is not considered in this summary table. Scapular, humeral, and clavicular elements are separately indicated when the pectoral bones and associated muscles are not group within the same module

${ }^{a}$ no clear assignment of $\mathrm{C} 5$ to the midcervical or lower cervical module

b potential subdivision of the midcervical module into $\mathrm{C} 2 / \mathrm{C} 3$ and $\mathrm{C} 4 / \mathrm{C} 5$

c no clear assignment of $\mathrm{C} 2$ to the cranio-atlantal or midcervical module

${ }^{d}$ no clear division between the cranio-atlantal and ventral module 

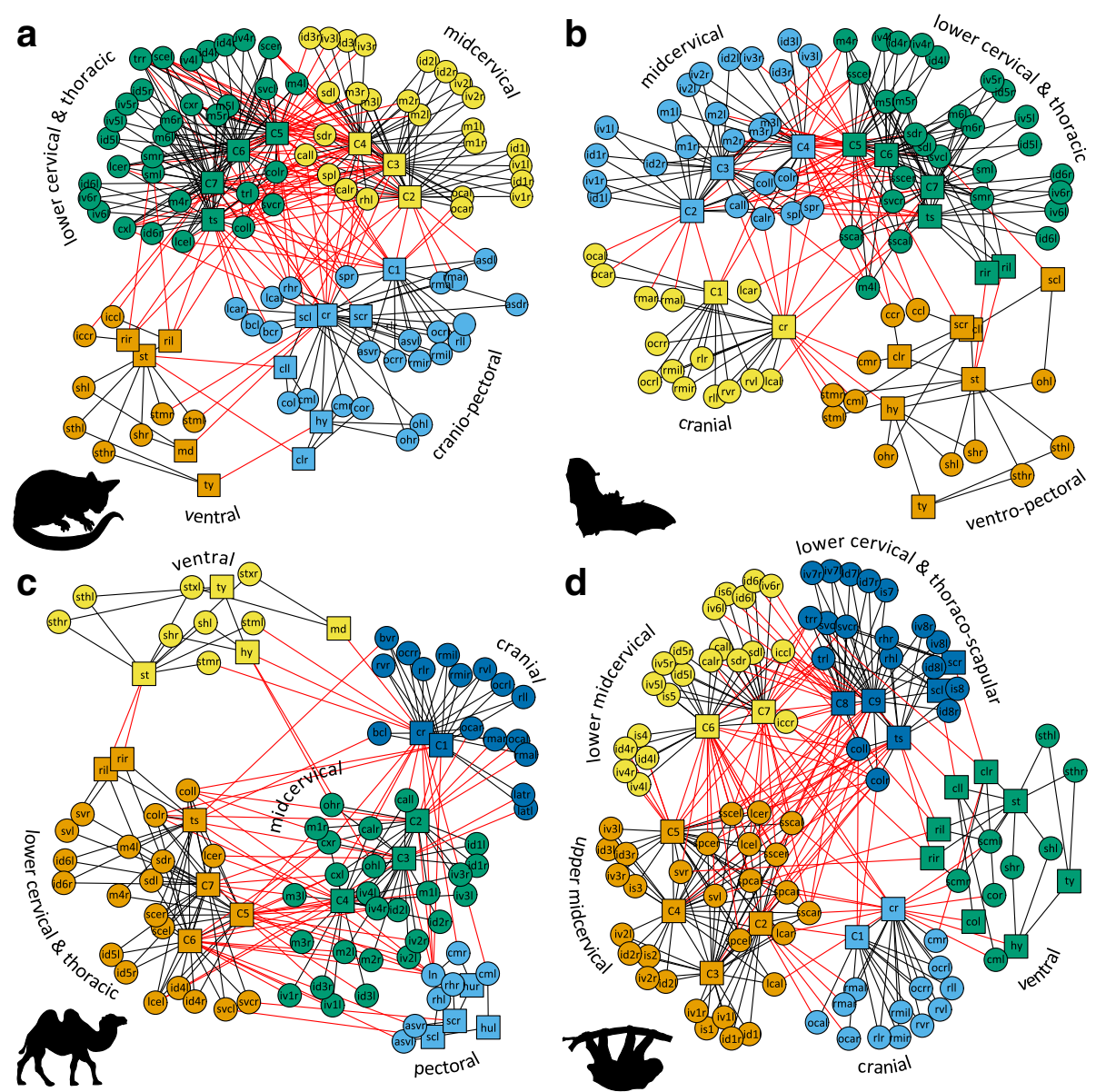

Fig. 4 Network representations and connectivity modules of the neck of different mammals. a Common brushtail possum (Trichosurus vulpecula); (b) Parti-coloured bat (Vespertilio murinus); (c) Bactrian camel (Camelus bactrianus); (d) Three-toed sloth (Bradypus tridactylus). Colors code for the identified connectivity modules. Red links between-modules. Black links within modules

is mostly limited to xenarthrans, chiropterans, and some cetartiodactyls. Although relatively species-poor, xenarthrans, show highly specialized neck morphologies related to their diverse fossorial or arboreal ecologies [79-81] and unique development $[33,82,83]$. In chiropterans, back muscles contribute only marginally to the stabilization of the head because of the lack of most cranial and cervical attachments [84-86]. Sagittal stability is instead achieved by the modified morphology of the cervical vertebrae in accordance with roosting behaviors [87]. Cetartiodactyls have recently been show to exhibit the highest disparity in neck morphology across mammals [31]. It ranges from the very short necks of cetaceans up to the extreme long ones of camelids and giraffids. As a consequence, neck musculoskeletal organization is similarly diverse. Several muscles with cervical attachment are reduced in the Pygmy sperm whale (and other cetaceans) or their attachment is shifted to the skull (e.g. scaleni muscles) and thus head stabilization is increased $[88,89]$. On the other hand, cranial attachments of the dorsal neck muscle are mainly reduced in long necked species, such as the camel and giraffe. Muscle force is instead transferred by the modified nuchal ligament $[74,75,77]$. Surprisingly, neck network parameters in the dugong (Dugong dugon), although also being fully aquatic, do not show a similar alteration as in the Pygmy sperm whale. Instead, it closely resembles the Asian elephant (Elephas maximus) and other afrotherians (Table 1, Fig. 2).

In accordance with our findings, [90, 91] also showed that the effect of size and prey capture behavior is low in the neck compared to the thoracolumbar region. However, functional interpretations of the results of the analysis of the topological arrangement of parts needs to be inferred on a one to one basis and taking into account the specific ecological context of each taxa.

\section{Regionalization and modularity in the mammalian neck}

Despite the relative low and invariant number of neck vertebrae in mammals, several studies have uncovered a tripartite regionalization of the cervical spine based on 
developmental, morphological, allometric, and functional evidence $[17,25,31,32,91]$. Our results have now uncovered a corresponding regionalization of the musculoskeletal organization of the mammalian neck into an upper (cranium, C1), mid (C2-C4), and lower cervical module ( $\mathrm{C} 5-\mathrm{C} 7$, in some species also the thoracic spine). This modularity pattern is conserved across mammals despite variations in size, feeding mechanisms, and locomotor modes (indicated by a uniform grade of modularity). This conserved pattern probably arose from the high number of connections between the vertebrae of the same module (or the cranium and $\mathrm{C} 1$ ) resulting in an increase of structural constraints and integration of these elements $[40,49,52]$. However, the boundaries between adjacent modules/regions are not consistent across different studies analyzing the morphology of the neck using different criteria. For example, vertebrae $\mathrm{C} 1$ and $\mathrm{C} 2$ are not part of the same connectivity module despite their close developmental, functional, and evolutionary relationship [25, 92, 93]. A similar dissociation of $\mathrm{C} 1$ and $\mathrm{C} 2$ into different regions has been shown for their scaling properties [31] and highlights the role of $\mathrm{C} 2$ as a functional mediator between the head joint and the postaxial column (see also [94]). In addition to the three 'inner' axial modules, there are two additional 'outer' modules bridging the distance between the trunk and the head (or the hyoid or upper vertebrae), with a muscular cuff on the dorso-lateral (pectoral) and ventrolateral side. Many of these muscles were crucial for the evolutionary origin of the vertebrate neck $[95,96]$.

\section{Neck organization in sloths}

In general, a similar regionalization of the neck is observed in both genera of sloths, despite their variation in the number of cervical vertebrae. The evolutionary new C8 and C9 in Bradypus and their associated muscles are grouped together with the thoracic spine. This agrees with their thoracic origin and ossification sequence [82]. Conversely, the evolutionary new Th1 provides the basis for the close association of the thoracic vertebral region to $\mathrm{C} 5$ and $\mathrm{C} 6$ in Choloepus neck organization. Divergence of the sloths' necks becomes obvious when including their pectoral bones and muscles in the comparison. Their neck-shoulder arrangement represents two different solutions of locomotor possibilities under common functional constraints [80, 97]. Neck organization and modularity of Bradypus resembles those of other long necked species. The resemblance stems from its nearly complete lack of cervical and cranial attachments of the neck/shoulder muscles and its unusual clavicular and shoulder morphology [80, 98-100] (see the unusual lower cervical-thoracic-scapular module in Table 4). The muscles of Choloepus, in contrast, are so placed as to offer the greatest possible support dorsally and ventrally to the head as well as to the scapula $[80,98,101$,
102]. Thus, neck organization and modularity is closer to the general pattern as seen in the lesser grison (i.e., pronounced head support, functional connection of head and forelimb) [15].

\section{Evolutionary integration of the neck and the forelimb}

The enduring evolutionary and developmental relationship between the neck and the forelimb in mammals (and other amniotes) is well documented (e.g., [17, 19, $20,95,96,103])$. This relationship is most obvious in the brachial plexus innervating shoulder and forelimb muscles $[104,105]$. However, there is also a strong functional integration between the neck and the forelimb, with several muscles connecting the pectoral girdle and the head/ neck (often with repeated slips). Based on this functional connection, the posture and movements of the neck have a crucial influence on the mechanics of the forelimb in terms of gait efficiency, balance, stabilization, ground reaction forces, and kinematics [30, 106-112]. Our findings now highlight the consequences of this integration on the musculoskeletal organization of the neck. Although there is a conserved tripartition of the cervical spine and its associated muscles, the varying contribution of pectoral bones and muscles to different connectivity modules accounts for much of the observable neck disparity across mammals (e.g., see results on sloths). Major shifts in forelimb morphology and function (e.g., mobilization of the pectoral girdle, reduction of the claviculae) [113-115] are associated with increasing decoupling of the pectoral elements from the ventral module and their connection to the cranium and upper cervical region. This coincides with the increased role of head/neck movements on forelimb mechanics during fast and endurance running (i.e., cursoriality) [30, 108]. In mammals with extreme long necks (camel, giraffe), although also being capable of enduring walking, the pectoral bones and muscles are separated from the cranial module. However, it has recently been shown that neck pendulum mechanics and function in long-necked mammals is different compared to actual cursors [108].

\section{Implications for the evolution and disparity of the mammalian neck}

The differences in neck organization between monotremes and therian mammals is one of the striking findings of this study. They result in high disparity between them whereas their within-subclade disparity is low during the first two-thirds of mammalian evolution. Accordingly, the disparity of the neck of mammals was low during the Mesozoic (Fig. 2f) [116]. Figure 5 illustrates the major grades of musculoskeletal organization during mammalian neck evolution. Monotreme, marsupial, and placental mammals differ in their degree of epaxonic muscle differentiation and the varying integration of the 


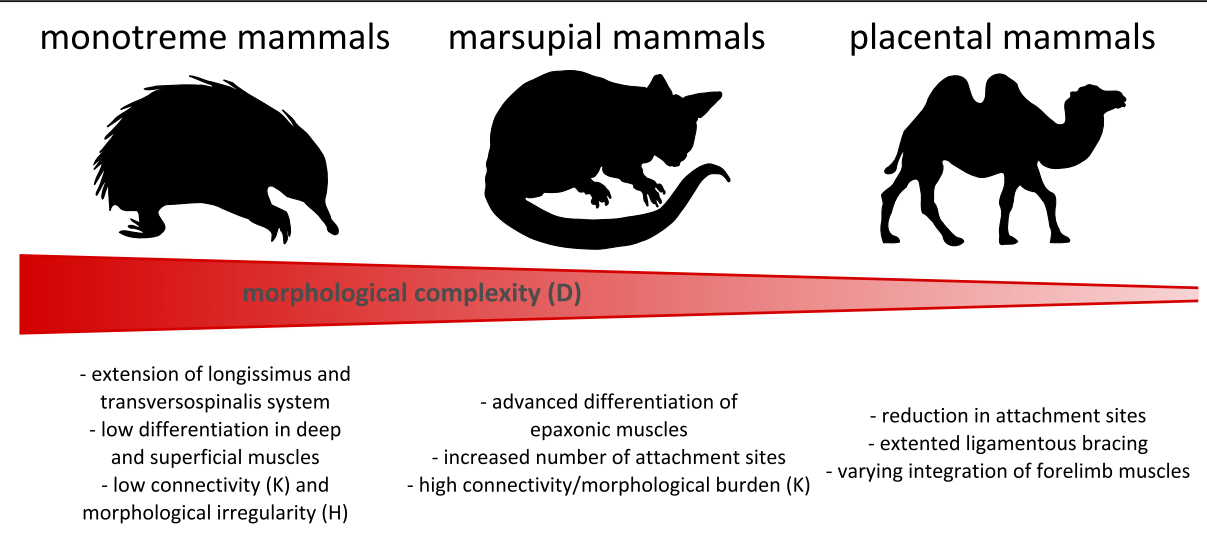

Fig. 5 Differences in the musculoskeletal organization of the neck between monotreme, marsupial, and placental mammals. In general. The morphological complexity of the neck (estimated by the density of connections D) decreases from monotreme to placental mammals (red bar) despite the disparity in neck organization and neck length among the latter

forelimb muscles. In general, the morphological complexity of the neck decreases from monotremes to placentals (Fig. 5) but disparity increases (Fig. 3).

The therian radiation that followed the $\mathrm{K} / \mathrm{T}$ mass extinction and the appearance of most of the therian and marsupial (supra)orders during the Paleocene was accompanied by an abrupt increase in neck musculoskeletal disparity after a long period of low neck disparity. This was even associated with the appearance of locomotor and foraging specializations [117] and the diversification in body size (e.g., [118]). The second disparity peak during the Eocene coincides with the radiation and increased diversity of modern placental orders, like cetartiodactyls, perissodactyls, carnivorans, and xenarthrans (see [117] and references therein). Thus, disparity in neck organization emerged relatively late in the long mammalian history and is associated with the origin and radiation of specific lineages.

\section{Conclusion}

One of our crucial findings is that the musculoskeletal organization of the neck differs between monotreme, marsupial, and placental mammals (Fig. 5). Moreover, particularly the necks of placental mammals are characterized by a reduced complexity despite their increased disparity in musculoskeletal organization and length. Our network analyses revealed a mosaic complexity and disparity in the musculoskeletal organization of the mammalian neck despite the more obvious meristic (and other) constraints on the cervical spine. Musculoskeletal irregularity, effective proximity, degree of modularity, and the occurrence of three inner/axial regions are conserved features among mammalian necks. Thus, a shared biomechanical construction and common developmental interrelationships not only constrain variation in the cervical spine, but are similarly likely to limit musculoskeletal variability in the neck. The conservation of these traits contrasts, however, with the high variability in morphological burden, integration by co-relation, morphological complexity, and the configuration of the ventral and (cranio-)pectoral module in the neck. The expansion of limb muscles in the cervical region not only facilitated enhanced forelimb mechanics but also increased structural disparity (and thus derived motor patterns and mechanics) in the neck. Thus, we highlight the close integration of the neck and the forelimb during mammalian evolution. The disparity in neck musculoskeletal organization evolved late in mammalian history and in parallel with the radiation of some lineages (e.g., cetartiodactyls, xenarthrans). Finally, our findings show that the limited number of vertebrae in the cervical spine does not necessarily result in low musculoskeletal disparity during mammalian evolutionary diversification.

\section{Methods}

Data collection and anatomical network modeling

We collected the topographic data of the musculoskeletal system of the neck in 48 mammalian species through an extensive literature review (Table 2, Additional file 2: AF2). The sample represents all major monotreme, marsupial, and placental clades, as well a diversity of locomotor and feeding strategies. Rodent diversity is represented by members of all suborders (sciuromorphs, myomorphs, hystricomorphs, castorimorphs, and anumaluromorphs, respectively). Representatives of both genera of extant sloth (Bradypus and Choloepus) were included to examine the influence of their deviating number of cervical vertebrae on neck organization. We documented the number and specific connections/attachments of all skeletal structures and muscles constituting the neck motion system in these taxa.

In contrast to the domestic mammals, for which veterinary textbooks as well as anatomical publications are available, information for exotic species is scarce and literature 
descriptions are in many cases old. To overcome this problem, in all but two cases we always consulted two or more references to compare the data. We made sure that at least one detailed anatomical monograph was included. As the network models used here focus on the presence/ absence of attachments among bones and muscles rather than more specific information on the nature and area of such attachments, the literature reviewed was of enough quality for our modeling approach.

We included all muscles originating from the cervical vertebrae, skull (cranium or mandible), nuchal ligament, or hyoid/thyroid, and inserting on the (cervical or thoracic) vertebrae, sternum, pectoral girdle (scapulae, claviculae, humeri), or ribs (see details in Additional file 3: AF3). Accordingly, we excluded the masticatory, facial, laryngeal, pharyngeal, and suprahyoid muscles from the analysis. A calibrated phylogenetic tree was constructed using the data from the Timetree of Life database $[119,120]$ (Fig. 2).

We built anatomical network models of the necks' musculoskeletal systems, which comprised all anatomical units as well as the different types of physical interaction among them. Network nodes represented all bones (cranium, cervical vertebrae, thoracic spine, left and right ribs, hyoid, left and right claviculae, left and right scapulae, sternum, and, if involved, left and right humeri, and mandible), other passive elements (nuchal ligament, if present, thyroid), and all cervical muscles, as described above. Network connections represented all physical articulations between bones and other passive elements described, as well as the fleshy and tendinous attachments of the muscles onto the bones (see adjacency matrices in Additional file 4: AF4). Network models were analyzed using the igraph package [121] in R [122].

\section{Network parameter analyses}

The mathematical definitions and calculations of the network parameters examined here $(N, K, D, C, L, H, P)$ are provided in Table 1 . The degree of modularity (parcellation $P$ ) was measured from the connectivity modules identified using a spin-glass model and simulated annealing algorithm implemented in the $\mathrm{R}$ package netcarto $[123,124]$. A connectivity module is defined as a group of nodes highly connected among them and poorly connected to nodes outside the group. $P$ is 0 when all nodes are in a same module, and tends to 1 when nodes are evenly distributed within many modules. We tested the phylogenetic signal in the multivariate dataset of all network parameters by calculating $\mathrm{K}_{\text {mult }}$ [125] using R package phylocurve [126]. We additionally tested the phylogenetic signal of the individual parameters using the Abouheif's test with 1000 permutations [127] and Blomberg's test [128] in the R package phytools [129]. Mode of trait evolution was explored by comparing multivariate fits of Brownian motion, Ornstein-Uhlenbeck (single adaptive optimum), and Early burst models using Akaike information criterion (AIC) weights in R package $m v M O R P H$
[130]. Distribution of the network parameters was visualized with a phylomorphospace of the first two principal components using R package phytools [129].

Relative variability of the network parameters was analyzed by statistical comparison of their coefficients of variation (CVs). 95\% confidence intervals of the CVs were calculated by 10,000 bootstrap resampling. Significant differences among the parameters' CVs were tested using the modified signed-likelihood ratio test (MSLRT) for equality of CVs (all parameters) and the asymptotic test for the equality of CVs (pair-wise comparisons, Bonferroni corrected) in the R package cvequality [131]. In order to test for allometric effects on network parameters they were regressed against logtransformed body mass, absolute neck length, and relative neck length. Body mass and neck length data were taken from [31]. Relative neck lengths were calculated by dividing absolute neck length by body mass ${ }^{1 / 3}$. Allometric analyses were done using phylogenetic generalized least square regressions in the $\mathrm{R}$ package caper [132]. The effect of predatory behavior on logtransformed network parameters was examined by testing for significant differences between predatory and non-predatory mammals using a multivariate distance-based phylogenetic generalized least square regression (D-PGLS) with 1000 permutations in the $\mathrm{R}$ package geomorph [133]. Species were classified as predatory when food intake involves head-neck movements to hold the food counteracting its resisting movements (carnivorous, insectivorous, piscivorous species). In contrast, species were classified as non-predatory when food intake does not involve such head-neck movements (food is just picked or harvested, e.g., browsers, grazers, but also myrmecophagous species). Differences in network parameters between monotreme, marsupial, and placental mammals were tested using a multivariate DPGLS regression with 1000 permutations.

\section{Modularity analysis}

We calculated the quality of the partitions identified by the community detection algorithm using the optimization function Q [134]. According to Newman and Girvan [134], if the number of connections within modules is not different from that expected at random, then $\mathrm{Q}$ will be close to 0 . The higher the $Q$ the stronger the modular pattern of the network $\left(\mathrm{Q}_{\max }=1\right)$. In practice, strongly modular networks show $Q$ values ranging from 0.3 to 0.7 [134]. Thus, we considered that an anatomical network has a strongly modular structure if $\mathrm{Q}-\mathrm{Q}_{\text {error }}>0.3$. The expected error of $\mathrm{Q}$ was calculated using a jackknife procedure, where every link was taken as an independent observation [134] (more details are provided in Additional file 3: AF3). Finally, we estimated the statistical significance of each module using a two-sample Wilcoxon rank-sum test on the internal vs. external links of the module's nodes. The null hypothesis was that the number of connections is the same inside as outside the module 
(i.e., as expected if the module were created at random); the alternative hypothesis was that the number of connections is higher inside than outside the module (i.e., the definition of connectivity module). An extensive account of these methods has been given elsewhere [41, 48, 135].

\section{Disparity through time analysis}

We carried out a disparity through time (DTT) analysis using the R package geiger [136] to trace the variation in neck organization through the evolution of mammals. First, we performed a principal component analysis (PCA) of the network parameters used as proxies of the morphological organization of the neck (i.e., $N, K, C, D$, $L, H$, and $P$ ) to account for their co-variation structure. Mean subclade disparity through time for the PC scores were calculated $[116,137]$. Observed disparity in neck organization across our phylogeny was compared with that expected under a Brownian motion process performing 10,000 iterations. High disparity values indicate high variance within subclades; low disparity values indicate conservation within subclades and high variance among subclades. Finally, we calculated the morphological disparity index to quantify the overall difference in relative disparity of a clade compared to that expected under the null Brownian motion model $[116,137]$.

\section{Abbreviations of network elements}

Left and right side are indicated by $l$ and $r$, respectively, added to the abbreviations.

asd atlantoscapularis dorsalis; asv atlantoscapularis ventralis; $b c$ biventer cervicis; $C 1-C 9$ cervical vertebrae; cal longus capitis; $c c$ cleidocervicalis; $c l$ clavicle; $c m$ cleidomastoideus; $c o$ cleidooccipitalis; col longus colli; $c x$ complexus; $\mathrm{cr}$ cranium; $h u$ humerus; $h y$ hyoid; icc iliocostalis cervicis; id1-id8 intertransversarii cervicis dorsales; im1-im4 intertransversarii cervicis mediales; is1-is8 interspinalis; $i v / i v 1-i v 8$ intertransversarii cervicis ventrales (fused/separate); lat longus atlantis; lca longissimus capitis; lce longissimus cervicis; In nuchal ligament; m1-m6 multifidi; $m d$ mandible; oca obliquus capitis caudalis; ocr obliquus capitis cranialis; oh omohyoideus; $r c a$ rhomboideus capitis; $r c e$ rhomboideus cervicis; $r c i$ rectus capitis dorsalis intermedius; $r h$ rhomboideus (undifferentiated); $r i$ ribs; $r l$ rectus capitis lateralis; $r m a$ rectus capitis dorsalis major; rmi rectus capitis dorsalis minor; $r v$ rectus capitis ventralis; sce spinalis cervicis; $s c$ scapula; $\mathrm{scm}$ sternocleidomastoideus (sternal and clavicle part not separate); $s d$ scalenus dorsalis; $s h$ sternohyoideus; $s m$ scalenus medius; so sternooccipitalis; spca splenius capitis; spce splenius cervicis; $s p$ splenius (undifferentiated); ssca semispinalis capitis; ssce semispinalis cervicis; $s t$ sternum; sth sternothyroideus; stm sternomastoideus; $s t x$ sternomaxillaris; $s v c$ serratus ventralis cervicis; $s v$ scalenus ventralis; $t r$ trapezius; $t s$ thoracic spine; $t y$ thyroid

\section{Additional files}

Additional file 1: AF1 Additional information on the results of phylogenetic, network, and modularity analyses. (PDF $1108 \mathrm{~kb}$ )

Additional file 2: AF2 Systematics and references of investigated species. (PDF $414 \mathrm{~kb}$ )

Additional file 3: AF3 Additional information on methods. (PDF $210 \mathrm{~kb}$ )

Additional file 4: AF4 Adjacency matrices coding for the topological information of neck's musculoskeletal organization of investigated species. (XLS $677 \mathrm{~kb}$ )

\section{Acknowledgements}

We thank Heiko Stark for helpful discussions, Jan Wölfer for assistance with the phylogentic comparative methods, and Mikaela Lui for language improvement. We are grateful to associated editor Leandro Monteiro and two anonymous reviewers who improved the manuscript with their helpful suggestions.

\section{Funding}

PA is funded by the Max Planck Society. BE-A is funded by the European Union's Horizon 2020 research and innovation program under the Marie Skłodowska-Curie grant agreement No 654155. The funding supported the experimental design and execution of the work described in this study. The funding institution had no influence on the analysis and interpretation of the data.

\section{Availability of data and materials}

All data generated and analyzed during this study are included in this published article and its additional information files. Raw data (i.e., the adjacency matrices) are provided in the additional information files.

\section{Authors' contributions}

PA and MSF designed the study. PA collected all data and prepared the manuscript and figures. PA and BE-A analyzed the data. All authors contributed to the interpretation of the results. All authors have read approved the manuscript.

Ethics approval and consent to participate

Not applicable

Consent for publication

Not applicable

Competing interests

The authors declare that they have no competing interests.

\section{Publisher's Note}

Springer Nature remains neutral with regard to jurisdictional claims in published maps and institutional affiliations.

\section{Author details}

'Department of Human Evolution, Max Planck Institute for Evolutionary Anthropology, Leipzig, Germany. ${ }^{2}$ Institut für Spezielle Zoologie und Evolutionsbiologie mit Phyletischem Museum, Friedrich-Schiller-Universität Jena, Jena, Germany. ${ }^{3}$ Structure \& Motion Lab, Department of Comparative Biomedical Sciences, Royal Veterinary College, Hatfield, UK.

Received: 31 May 2017 Accepted: 30 November 2017

Published online: 13 December 2017

References

1. Alexander R, Dimery NJ, Ker R. Elastic structures in the back and their role in galloping in some mammals. J Zool. 1985;207(4):467-82.

2. Bramble DM, Carrier DR. Running and breathing in mammals. Science. 1983; 219(4582):251-6.

3. Fischer MS. Crouched posture and high fulcrum, a principle in the locomotion of small mammals: the example of the rock hyrax (Procavia capensis)(Mammalia: Hyracoidea). J Hum Evol. 1994;26(5-6):501-24.

4. Gambaryan PP, Hardin H. How mammals run: anatomical adaptations. New York: Wiley; 1974. 
5. Hildebrand M. Motions of the running cheetah and horse. J Mammal. 1959:40(4):481-95.

6. Magne de la Croix P. The evolution of locomotion in mammals. J Mammal. 1936;17(1):51-4

7. Asher R, Lin K, Kardjilov N, Hautier L. Variability and constraint in the mammalian vertebral column. J Evol Biol. 2011;24(5):1080-90.

8. Buchholtz EA: Flexibility and constraint: patterning the axial skeleton in mammals. In: From clone to bone: the synergy of morphological and molecular tools in Palaeobiology. Edited by Asher R, Müller J. Cambridge: Cambridge University Press; 2012: 230-256.

9. Galis F. Why do almost all mammals have seven cervical vertebrae? Developmental constraints, Hox genes, and cancer. J Exp Zool. 1999;285(1):19-26.

10. Galis F, Carrier DR, Van Alphen J, Van Der Mije SD, Van Dooren TJ, Metz JA, ten Broek CM. Fast running restricts evolutionary change of the vertebral column in mammals. Proc Natl Acad Sci. 2014;111(31):11401-6.

11. Müller J, Scheyer TM, Head JJ, Barrett PM, Werneburg I, Ericson PG, Pol D, Sánchez-Villagra MR. Homeotic effects, somitogenesis and the evolution of vertebral numbers in recent and fossil amniotes. Proc Natl Acad Sci. 2010;107(5):2118-23.

12. Narita $Y$, Kuratani S. Evolution of the vertebral formulae in mammals: perspective on developmental constraints. J Exp Zool B Mol Dev Evol. 2005;304(2):91-106.

13. Sánchez-Villagra MR, Narita Y, Kuratani S. Thoracolumbar vertebral number: the first skeletal synapomorphy for afrotherian mammals. Syst Biodivers. 2007;5(1):1-7

14. Todd TW. Numerical significance in the thoracicolumbar vertebrae of the mammalia. Anat Rec. 1922;24(5):260-86.

15. Jouffroy F. Evolution of the dorsal muscles of the spine in light of their adaptation to gravity effects. In: Berthoz A, Graf W, Vidal PP, editors. The headneck sensory motor system. Oxford: Oxford University Press; 1992. p. 22-35.

16. Slijper EJ. Comparative biological-anatomical investigations of the vertebra column and spinal musculature. K Ned Akad Wet, Verh (Tweede Sectie). 1946:42:1-128.

17. Buchholtz EA, Bailin HG, Laves SA, Yang JT, Chan MY, Drozd LE. Fixed cervical count and the origin of the mammalian diaphragm. Evol Dev. 2012;14(5):399-411.

18. Burke AC, Nowicki J. A new view of patterning domains in the vertebrate mesoderm. Dev Cell. 2003;4(2):159-65.

19. Hirasawa T, Fujimoto S, Kuratani S. Expansion of the neck reconstituted the shoulder-diaphragm in amniote evolution. Develop Growth Differ. 2016:58(1):143-53.

20. Hirasawa T, Kuratani S. A new scenario of the evolutionary derivation of the mammalian diaphragm from shoulder muscles. J Anat. 2013;222(5):504-17.

21. Carrier DR, Deban SM, Fischbein T. Locomotor function of forelimb protractor and retractor muscles of dogs: evidence of strut-like behavior at the shoulder. J Exp Biol. 2008;211(1):150-62.

22. Deban SM, Schilling N, Carrier DR. Activity of extrinsic limb muscles in dogs at walk, trot and gallop. J Exp Biol. 2012;215(2):287-300.

23. English AWM. An electromyographic analysis of forelimb muscles during overground stepping in the cat. J Exp Biol. 1978;76(1):105-22.

24. Payne $R$, Veenman $P$, Wilson A. The role of the extrinsic thoracic limb muscles in equine locomotion. J Anat. 2004;205(6):479-90.

25. Graf W, De Waele C, Vidal P. Functional anatomy of the head-neck movement system of quadrupedal and bipedal mammals. J Anat. 1995;186(Pt 1):55.

26. Graf W, de Waele C, Vidal P, Wang D, Evinger C. The orientation of the cervical vertebral column in unrestrained awake animals. II. Movement strategies. Brain Behav Evol. 1995;45(4):209-31.

27. Hart BL, Hart LA, Mooring MS, Olubayo R. Biological basis of grooming behaviour in antelope: the body-size, vigilance and habitat principles. Anim Behav. 1992:44(4):615-31

28. Mooring MS, Blumstein DT, Stoner CJ. The evolution of parasite-defence grooming in ungulates. Biol J Linn Soc. 2004;81(1):17-37.

29. Vidal PP, Graf W, Berthoz A. The orientation of the cervical vertebral column in unrestrained awake animals. Exp Brain Res. 1986;61(3):549-59.

30. Zsoldos RR, Licka TF. The equine neck and its function during movement and locomotion. Zoology. 2015;118(5):364-76.

31. Arnold P, Amson E, Fischer MS. Differential scaling patterns of vertebrae and the evolution of neck length in mammals. Evolution. 2017;71(6):1587-1599.

32. Arnold P, Forterre F, Lang J, Fischer MS. Morphological disparity, conservatism, and integration in the canine lower cervical spine: insights into mammalian neck function and regionalization. Mamm BiologyZeitschrift für Säugetierkunde. 2016;81(2):153-62.

33. Buchholtz EA, Stepien CC. Anatomical transformation in mammals: developmental origin of aberrant cervical anatomy in tree sloths. Evol Dev. 2009;11(1):69-79.

34. Buchholtz EA, Wayrynen KL, Lin IW. Breaking constraint: axial patterning in Trichechus (Mammalia: Sirenia). Evol Dev. 2014;16(6):382-93.

35. Johnson D, McAndrew T, Oguz Ö. Shape differences in the cervical and upper thoracic vertebrae in rats (Rattus norvegicus) and bats (Pteropus poiocephalus): can we see shape patterns derived from position in column and species membership? J Anat. 1999;194(2):249-53.

36. Bekele A. The comparative functional morphology of some head muscles of the rodents Tachyoryctes splendens and Rattus rattus. II. Cervical muscles. Mammalia. 1983;47(4):549-72.

37. Diogo R. The head and neck muscles of the Philippine colugo (Dermoptera: Cynocephalus volans), with a comparison to tree-shrews, primates, and other mammals. J Morphol. 2009;270(1):14-51.

38. Diogo R, Wood B. Soft-tissue anatomy of the primates: phylogenetic analyses based on the muscles of the head, neck, pectoral region and upper limb, with notes on the evolution of these muscles. J Anat 2011;219(3):273-359.

39. Filan SL. Myology of the head and neck of the bandicoot (Marsupialia, Peramelemorphia). Aust J Zool. 1990;38(6):617-34.

40. Esteve-Altava B, Marugán-Lobón J, Botella H, Bastir M, Rasskin-Gutman D. Grist for Riedl's mill: a network model perspective on the integration and modularity of the human skull. J Exp Zool B Mol Dev Evol. 2013;320(8):489-500.

41. Rasskin-Gutman D, Esteve-Altava B. Connecting the dots: anatomical network analysis in morphological EvoDevo. Biol Theory. 2014;9(2):178-93.

42. Esteve-Altava B. In search of morphological modules: a systematic review. Biol Rev. 2017:92(3):1332-47.

43. Esteve-Altava B, Marugán-Lobón J, Botella H, Rasskin-Gutman D. Structural constraints in the evolution of the tetrapod skull complexity: Williston's law revisited using network models. Evol Biol. 2013;40(2):209-19.

44. Esteve-Altava B, Boughner JC, Diogo R, Villmoare BA, Rasskin-Gutman D. Anatomical network analysis shows decoupling of modular lability and complexity in the evolution of the primate skull. PLoS One. 2015;10(5):e0127653.

45. Diogo R, Esteve-Altava B, Smith C, Boughner JC, Rasskin-Gutman D. Anatomical network comparison of human upper and lower, newborn and adult, and normal and abnormal limbs, with notes on development, pathology and limb serial homology vs. homoplasy. PLoS One. 2015;10:e0140030.

46. Murphy AC, Muldoon SF, Baker D, Lastowka A, Bennett B, Yang M, Bassett DS. Structure, function, and control of the musculoskeletal network. In: arXiv preprint arXiv:161206336; 2016.

47. Dos Santos DA, Fratani J, Ponssa ML, Abdala V. Network architecture associated with the highly specialized hindlimb of frogs. PLoS One. 2017;12(5):e0177819.

48. Esteve-Altava B. Challenges in identifying and interpreting organizational modules in morphology. J Morphol. 2017;278(7):960-74.

49. Rasskin-Gutman D. Boundary constraints for the emergence of form. In: Müller GB, Newman SA, editors. Origination of Organismal form: beyond the gene in developmental and evolutionary biology. Camebridge: MIT Press; 2003. p. 305.

50. Rasskin-Gutman D, Buscalioni AD. Theoretical morphology of the Archosaur (Reptilia: Diapsida) pelvic girdle. Paleobiology. 2001;27(1):59-78.

51. Riedl R, Jefferies RPS. Order in living organisms: a systems analysis of evolution. New York: Wiley; 1978.

52. Schoch RR. Riedl's burden and the body plan: selection, constraint, and deep time. J Exp Zool B Mol Dev Evol. 2010;314(1):1-10.

53. Wagner GP, Laubichler MD. Rupert Riedl and the re-synthesis of evolutionary and developmental biology: body plans and evolvability. J Exp Zool B Mol Dev Evol. 2004;302(1):92-102.

54. Gregory WK. Polyisomerism and anisomerism in cranial and dental evolution among vertebrates. Proc Natl Acad Sci. 1934;20(1):1-9.

55. Eble GJ. Morphological modularity and macroevolution: conceptual and empirical aspects. In: Callebaut W, Rasskin-Gutman D, editors. Modularity: understanding the development and evolution of natural complex systems. Camebridge: The MIT Press; 2005. p. 221-38.

56. Goswami A, Smaers J, Soligo C, Polly P. The macroevolutionary consequences of phenotypic integration: from development to deep time. Philos Trans R Soc B: Biol Sci. 2014;369(1649):20130254.

57. Klingenberg CP. Morphological integration and developmental modularity. Annu Rev Ecol Evol Syst. 2008;39:115-32. 
58. Wagner GP, Pavlicev M, Cheverud JM. The road to modularity. Nat Rev Genet. 2007:8(12):921-31.

59. Buchholtz EA. Crossing the frontier: a hypothesis for the origins of meristic constraint in mammalian axial patterning. Zoology. 2014;117(1):64-9.

60. Galis F, Metz JA. Anti-cancer selection as a source of developmental and evolutionary constraints. BioEssays. 2003;25(11):1035-9.

61. Galis F, Van Dooren TJ, Feuth JD, Metz JA, Witkam A, Ruinard S, Steigenga MJ, Wunaendts LC. Extreme selection in humans against homeotic transformations of cervical vertebrae. Evolution. 2006;60(12):2643-54.

62. Kummer B. Bauprinzipien des Säugerskeletes Stuttgart. Germany: Georg Thieme Verlag; 1959

63. Kummer B: Biomechanik des Säugetierskeletts. In: Handbuch der Zoologie, Band 8 (6). Edited by Helmcke J-G, Legerken Hv, Starck D, vol. 24. Berlin: Walter de Gruyter \& Co. Verlag; 1959.

64. Coues E. On the myology of the Ornithorhynchus. Proc Essex Inst. 1871;6:127-73.

65. Jouffroy F, Lessertisseur J, Saban R. Particularités musculaires des Monotrémes - musculature post-craniénne. In: Grassé P-P, editor. Traité de Zoologie Mamifères, Tome XVI, Fac III. Paris: Masson et Cie editeurs; 1971. p. 679-836.

66. Nishi S. Zur vergleichenden Anatomie der eigentlichen (genuinen) Rückenmuskeln. Gegenbaurs Morphol Jahrb. 1916;50:167-318.

67. Virchow H. Die tiefen Rückenmuskeln des Ornithorhynchus. Gegenbaurs Morphol Jahrb. 1929;60:481-559.

68. Barbour RA. The musculature and limb plexuses of Trichosurus vulpecula. Aust J Zool. 1963;11(4):488-610.

69. Coues E, Wyman J. On the osteology and myology of Didelphys virginiana. Mem Boston Soc Nat Hist. 1872;2:41-154.

70. Jouffroy FK. Musculature épisomatique. In: Grassé PP, editor. Traité de Zoologie Mamifères, Tome XVI, Fac II. Paris: Masson et Cie editeurs; 1968. p. 479-548.

71. Jüschke S. Untersuchungen zur funktionellen Anpassung der Rückenmuskulatur und der Wirbelsäule quadrupeder Affen und Känguruhs. Anat Embryol. 1972;137(1):47-85.

72. Osgood WH, Herrick CJ, Obenchain JB. A monographic study of the American marsupial Caenolestes, with a description of the brain of Caenolestes by $\mathrm{C}$. Judson Herrick. Field Mus Nat Hist (Zool Ser). 1921;14:1-162.

73. Bianchi M. The thickness, shape and arrangement of elastic fibres within the nuchal ligament from various animal species. Anat Anz. 1988;169(1):53-66.

74. Dimery NJ, Alexander R, Deyst KA. Mechanics of the ligamentum nuchae of some artiodactyls. J Zool. 1985;206(3):341-51.

75. Endo H, Yamagiwa D, Fujisawa M, Kimura J, Kurohmaru M, Hayashi Y. Modified neck muscular system of the giraffe (Giraffa camelopardalis). Ann Anat-Anat Anz. 1997;179(5):481-5.

76. Gellman K, Bertram J. The equine nuchal ligament 1: structural and material properties. Vet Comp Orthop Traumatol. 2002;15(1):1-6

77. Mobarak A, Fouad S. A study on Lig. Nuchae of the one-humped camel (Camelus dromedarius). Anat Histol Embryol. 1977;6(2):188-90.

78. Preuschoft $\mathrm{H}$, Klein $\mathrm{N}$. Torsion and bending in the neck and tail of sauropod dinosaurs and the function of cervical ribs: insights from functional morphology and biomechanics. PLoS One. 2013;8:e78574.

79. Galliari FC, Carlini AA, Sánchez-Villagra MR. Evolution of the axial skeleton in armadillos (Mammalia, Dasypodidae). Mamm Biology-Zeitschrift für Säugetierkunde. 2010;75(4):326-33.

80. Miller RA. Functional adaptations in the forelimb of the sloths. J Mammal. 1935;16(1):38-51.

81. VanBuren CS, Evans DC. Evolution and function of anterior cervical vertebral fusion in tetrapods. Biol Rev. 2017;92:608-26.

82. Hautier L, Weisbecker V, Sánchez-Villagra MR, Goswami A, Asher RJ. Skeletal development in sloths and the evolution of mammalian vertebral patterning. Proc Natl Acad Sci. 2010;107(44):18903-8.

83. Varela-Lasheras I, Bakker AJ, van der Mije SD, Metz JA, van Alphen J, Galis F. Breaking evolutionary and pleiotropic constraints in mammals: on sloths, manatees and homeotic mutations. EvoDevo. 2011;2:11.

84. Macalister A. The myology of the Cheiroptera. Philos Trans R Soc Lond. 1872;162:125-71

85. Maisonneuve P. Traité de l'ostéologie et de la myologie du Vespertilio murinus, précédé d'un exposé de la classification des chéiroptèi et de considérations sur les moeurs de ces animaux. Paris: O. Doin; 1878.

86. Mori M. Muskulatur des Pteropus edulis. Okajimas Folia Anat Jpn. 1960;36(3-4):253-307.

87. Fenton MB, Crerar LM. Cervical vertebrae in relation to roosting posture in bats. J Mammal. 1984;65(3):395-403.

88. Howell A. Aquatic mammals. Springfield: Charles C Thomas; 1930.
89. Schulte HW, Smith MDF. The external characters, skeletal muscles, and peripheral nerves of Kogia breviceps (Blainville). Bull Am Mus Nat Hist. 1918;38:7-72.

90. Randau M, Cuff AR, Hutchinson JR, Pierce SE, Goswami A. Regional differentiation of felid vertebral column evolution: a study of 3D shape trajectories. Organ Divers Evol. 2017;17(1):305-19.

91. Randau M, Goswami A, Hutchinson JR, Cuff AR, Pierce SE. Cryptic complexity in felid vertebral evolution: shape differentiation and allometry of the axial skeleton. Zool J Linnean Soc. 2016;178:183-202.

92. Evans FG. The morphology and functional evolution of the atlas-axis complex from fish to mammals. Ann N Y Acad Sci. 1939;39(1):29-104.

93. Jenkins FA. The evolution and development of the dens of the mammalian axis. Anat Rec. 1969;164(2):173-84.

94. Bogduk N, Mercer S. Biomechanics of the cervical spine. I: normal kinematics. Clin Biomech. 2000;15(9):633-48.

95. Matsuoka T, Ahlberg PE, Kessaris N, lannarelli P, Dennehy U, Richardson WD, McMahon AP, Koentges G. Neural crest origins of the neck and shoulder. Nature. 2005;436(7049):347-55.

96. Ericsson R, Knight R, Johanson Z. Evolution and development of the vertebrate neck. J Anat. 2013;222(1):67-78.

97. Nyakatura JA. The convergent evolution of suspensory posture and locomotion in tree sloths. J Mamm Evol. 2012;19(3):225-34.

98. Humphry G. The myology of the limbs of the Unau, the Ai, the two-toed anteater, and the pangolin. J Anat Physiol. 1869;3:2-78.

99. Macalister A. On the myology of Bradypus Tridactylus; with remarks on the general mucular anatomy of the Edentata. Ann Mag Nat Hist. 1869;4(19):51-67.

100. Mackintosh H. On the myology of the genus Bradypus. Proc R Ir Acad. 1870;1:517-29.

101. Lucae JCG. Statik und Mechanik der Quadrupeden an dem Skelett und den Muskeln des Lemur und eines Choloepus. Abhandlungen der Senckenbergischen Naturforschenden Gesellschaft Frankfurt. 1884;13:1-92.

102. Mackintosh H. On the muscular anatomy of Choloepus didactylus. Proc R Ir Acad. 1875;1:66-67^69.

103. Gross MK, Moran-Rivard L, Velasquez T, Nakatsu MN, Jagla K, Goulding M. $L b \times 1$ is required for muscle precursor migration along a lateral pathway into the limb. Development. 2000;127(2):413-24.

104. Howell AB. Morphogenesis of the shoulder architecture. Part VI. Therian Mammalia. Q Rev Biol. 1937:12(4):440-63.

105. Miller RA. Comparative studies upon the morphology and distribution of the brachial plexus. Am J Anat. 1934;54(1):143-75.

106. Dunbar DC, Macpherson JM, Simmons RW, Zarcades A. Stabilization and mobility of the head, neck and trunk in horses during overground locomotion: comparisons with humans and other primates. J Exp Biol. 2008;211(24):3889-907.

107. Hirasaki E, Kumakura H. Head movements during locomotion in a gibbon and Japanese macaques. Neuroreport. 2004;15(4):643-7.

108. Loscher DM, Meyer F, Kracht K, Nyakatura JA. Timing of head movements is consistent with energy minimization in walking ungulates. Proc $R$ Soc $B$. 2016;283:20161908.

109. Runciman RJ, Richmond FJ. Shoulder and forelimb orientations and loading in sitting cats: implications for head and shoulder movement. J Biomech. 1997;30(9):911-9.

110. Weishaupt M, Wiestner T, Peinen K, Waldern N, Roepstorff L, Weeren R, Meyer $\mathrm{H}$, Johnston $\mathrm{C}$. Effect of head and neck position on vertical ground reaction forces and interlimb coordination in the dressage horse ridden at walk and trot on a treadmill. Equine Vet J. 2006;38(\$36):387-92.

111. Zsoldos R, Kotschwar A, Kotschwar A, Groesel M, Licka T, Peham C. Electromyography activity of the equine splenius muscle and neck kinematics during walk and trot on the treadmill. Equine Vet J. 2010;42(s38):455-61.

112. Zubair HN, Beloozerova IN, Sun H, Marlinski V. Head movement during walking in the cat. Neuroscience. 2016;332:101-20.

113. Eaton TH. Modifications of the shoulder girdle related to reach and stride in mammals. J Morphol. 1944;75(1):167-71.

114. Jenkins FA. The movement of the shoulder in claviculate and aclaviculate mammals. J Morphol. 1974;144(1):71-83.

115. Schmidt M, Voges D, Fischer MS. Shoulder movements during quadrupedal locomotion in arboreal primates. Z Morphol Anthropol. 2002;83:235-42.

116. Harmon $\amalg$, Schulte JA, Larson A, Losos JB. Tempo and mode of evolutionary radiation in iguanian lizards. Science. 2003;301(5635):961-4.

117. Janis C. Tertiary mammal evolution in the context of changing climates, vegetation, and tectonic events. Annu Rev Ecol Syst. 1993;24(1):467-500

118. Slater GJ. Phylogenetic evidence for a shift in the mode of mammalian body size evolution at the cretaceous-Palaeogene boundary. Methods Ecol Evol. 2013;4(8):734-44. 
119. Timetree of Life Database [http://timetreebeta.igem.temple.edu]. Accessed 22.11.2016.

120. Hedges SB, Marin J, Suleski M, Paymer M, Kumar S. Tree of life reveals clocklike speciation and diversification. Mol Biol Evol. 2015;32:835-45.

121. Csardi G, Nepusz T. The igraph software package for complex network research. Int J Complex Syst. 2006;1695(5):1-9.

122. R Core Team. R: a language and environment for statistical computing. Vienna, Austria: R Foundation for Statistical Computing; 2016.

123. Network cartography - Netcarto [http://seeslab.info/downloads/networkcartography-netcarto/]. Accessed 02.10.2016.

124. Guimera R, Amaral LAN. Functional cartography of complex metabolic networks. Nature. 2005;433(7028):895-900.

125. Adams DC. A generalized $\mathrm{K}$ statistic for estimating phylogenetic signal from shape and other high-dimensional multivariate data. Syst Biol. 2014;63(5):685-97.

126. Goolsby EW. Phylogenetic comparative methods for evaluating the evolutionary history of function-valued traits. Syst Biol. 2015;64(4):568-78.

127. Abouheif E. A method for testing the assumption of phylogenetic independence in comparative data. Evol Ecol Res. 1999;1(8):895-909.

128. Blomberg SP, Garland T Jr, Ives AR, Crespi B. Testing for phylogenetic signal in comparative data: behavioral traits are more labile. Evolution. 2003;57(4):717-45.

129. Revell LJ. Phytools: an R package for phylogenetic comparative biology (and other things). Methods Ecol Evol. 2012;3(2):217-23.

130. Clavel J, Escarguel G. Merceron G: mvMORPH: an R package for fitting evolutionary models to morphometric data. Methods Ecol Evol. 2015;6(11):1311-9.

131. Marwick B, Krishnamoorthy K: cvequality: Tests for the Equality of Coefficients of Variation from Multiple Groups. 2016. R package version 0.1 1. https://CRAN.R-project.org/package= crequality.

132. Orme D, Freckleton R, Thomas G, Petzoldt T, Fritz S, Isaac N, Pearse W: caper: Comparative Analyses of Phylogenetics and Evolution in R. 2013. R package version 0.5.2. https://CRAN.R-project.org/package=caper.

133. Adams DC, Collyer ML, Kaliontzopoulou A, Sherratt E: Geomorph: Software for geometric morphometric analyses. 2013. R package version 3.0.5. https:// CRAN.R-project.org/package $=$ geomorph

134. Newman ME, Girvan M. Finding and evaluating community structure in networks. Phys Rev E. 2004;69(2):026113.

135. Esteve-Altava B, Marugán-Lobón J, Botella H, Rasskin-Gutman D. Network models in anatomical systems. J Anthropol Sci. 2011;89:1-10.

136. Harmon L, Weir JT, Brock CD, Glor RE, Challenger W. GEIGER: investigating evolutionary radiations. Bioinformatics. 2008;24(1):129-31.

137. Slater GJ, Price SA, Santini F, Alfaro ME. Diversity versus disparity and the radiation of modern cetaceans. Proc R Soc Lond B Biol Sci. 2010;277(1697):3097-104.

138. Ercoli MD, Álvarez A, Busker F, Morales MM, Julik E, Smith HF, Adrian B, Barton M, Bhagavatula K, Poole M. Myology of the head, neck, and thoracic region of the lesser Grison (Galictis cuja) in comparison with the red panda (Ailurus fulgens) and other carnivorans: phylogenetic and functional implications. J Mamm Evol. 2017;24(3):289-322.

139. Ercoli MD, Álvarez A, Stefanini MI, Busker F, Morales MM. Muscular anatomy of the forelimbs of the lesser grison (Galictis cuja), and a functional and phylogenetic overview of Mustelidae and other Caniformia. J Mamm Evol. 2015;22(1):57-91.

\section{Submit your next manuscript to BioMed Central and we will help you at every step:}

- We accept pre-submission inquiries

- Our selector tool helps you to find the most relevant journal

- We provide round the clock customer support

- Convenient online submission

- Thorough peer review

- Inclusion in PubMed and all major indexing services

- Maximum visibility for your research

Submit your manuscript at www.biomedcentral.com/submit
Biomed Central 